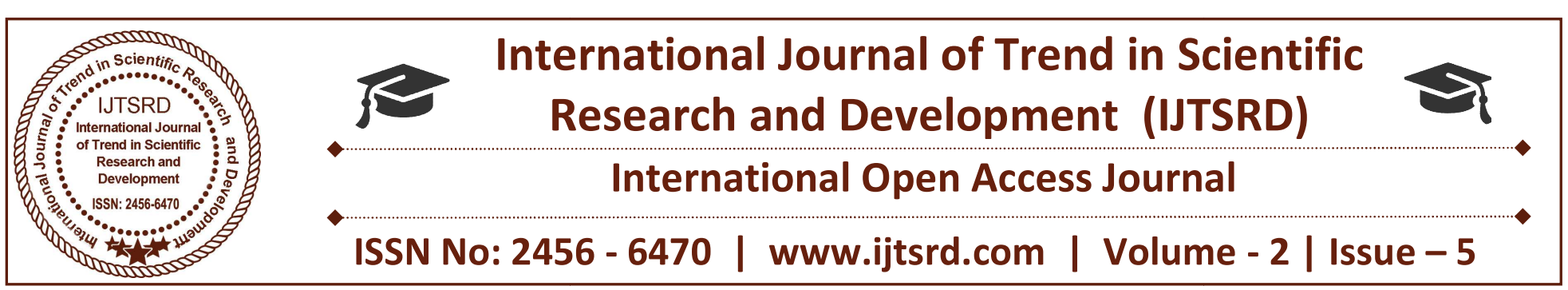

\title{
Human Resource, Marketing and Environmental Management on Financial Performance of Manufacturing Firms Listed at the Nairobi Securities Exchange, Kenya
}

\author{
Michael Ochieng' Oloo \\ Degree in Master of Business Administration (Finance), \\ Kenyatta University, Nairobi, Kenya
}

\section{ABSTRACT}

Manufacturing is an important sector as it contributes to the country's economic development and growth. It has the potential to generate foreign exchange earnings through exports and diversify the country's economy. It is the platform through which Kenya intends to achieve its development goals of Vision 2030. The problem in the sector is huge untapped potential resources which if not checked can lead to economic crisis and also the high cost of production. Other than financial factors, financial performance of manufacturing listed firms can be affected by issues concerning selection and recruitment, training and development, succession and career path, marketing planning, market analysis and evaluation, marketing control, laws and regulation compliance, recycling of wastes and environmental planning. The study specifically determined the extent to which human resource management, marketing management, and environmental management affected the financial performance in manufacturing companies listed in the NSE in Kenya. The study was a descriptive research survey and it covered a period of the past five years from 2011 to 2015 . The target population was staff in various departments like accounts, human resources, marketing and production in ten listed manufacturing firms at the NSE. Since the population was small and variable, census was conducted to gather information. From a population of ten manufacturing firms, a sample size of one hundred and two respondents was chosen from ten firms. The primary data was collected using a questionnaire which had both open and closed ended questions. Secondary data was also used in the research. Secondary data was collected from Management accounts of the companies and other parameters were collected from Kenya National Bureau of Statistics, Nairobi Securities Exchange and Central Bank of Kenya records. The collected data was analyzed through descriptive and inferential statistics. Descriptive analysis included measures of association like Chi-Square test which was used to find out the relationship between the independent and dependent variables. The analyzed data was presented in form of tables and charts for easy understanding and interpretation. The results from the Chi-Test indicated that there was positive and significant relationship between human resource, marketing and environmental management components and financial performance given positive P-Values tabulated. The analysis was done using SPSS 22.0. The study concluded that human resource; marketing and environmental management positively and significantly affected financial performance of manufacturing companies listed at Nairobi Securities Exchange market in Kenya. The study further concluded that manufacturing companies listed at Nairobi Securities Exchange market in Kenya should consider Environmental, Human Resource and Marketing Management for their good financial performance. The study recommended that Environmental, Human Resource and Marketing Management should be employed by manufacturing companies listed at Nairobi Securities Exchange market in Kenya since the results showed positive and significant effect on the financial performance of manufacturing firms. The study also recommended that Environmental, Human Resource and Marketing Management were strong variables and with a positive significance level thus they should be 
employed also in public sectors corporate institutions and NGOs.

\section{INTRODUCTION}

\subsection{Background of the Study}

Understanding the channels through which manufacturing growth has an impact on economies wide growth and development and employment in particular is essential for considering how manufacturing can mobilize higher growth and employment creation. The management of any company would like to identify and eliminate the underlying causes of inefficiencies, thus helping their firms to gain competitive advantage and attain sustainable competitive advantage, or at least, withstand the challenges from others (Yang, 2006). According to Thompson (2007), the significant challenges for complex organizations are posed by contingencies and therefore a firm should properly design their organizational factors to be contingent in order to specifically address them than operating under earlier strategic arrangement. In the dynamic and volatile environments in which most manufacturing companies operate today, flexibility of organizational factors is a valuable capability for competitive advantage (Schmenner \& Tatikonda, 2005). However, in the process of adopting the techniques of manufacturing flexibilities, firms still find it challenging to realize benefits towards performance (Anderson, 2013)

Nicholas Kaldor developed a set of hypotheses or stylized facts to explain the central role of manufacturing in the process of economic development. He argued that manufacturing demonstrates a unique characteristic: the capacity to generate 'dynamic increasing returns'. That is, manufacturing not only has the potential to increase its output more than proportionate to the increase in inputs, but also: the faster the rate of growth of output in manufacturing, the faster the rate of growth of both manufacturing and economy-wide productivity (Thirlwall, 2005). The sector plays an important role in adding value to agricultural output and providing forward and backward linkages, hence accelerating overall growth. By the year 2003 the manufacturing sector comprised more than 700 established enterprises and directly employed over 218,000 persons as at the year 2000 (Kenya Association of Manufacturers, 2011).

\subsubsection{Human Resource, Environmental Management}

Marketing

Financial goals drive higher profits, but non-financial company objectives also aid in improving the company as a whole. The non-financial improvements help round out the company's strengths in areas like customer service, production quality and employee satisfaction. These areas create a stronger company as a whole that is able to perform better in the market, increasing profits (Jackson, 2008)

HRM has attracted attention from academics and practitioners as a tool to improve organizational financial performance and employee outcomes such as work satisfaction and to lower job stress (Preuss, 2003). It should also be admitted that strategic HRM typically means making investment in HRM practices that enhance financial outcomes (Boudreau, 2003). Although human resources and their management are recognized as critical for organizational success (Guest, 2011), it is assumed that in the practice human resources are consumed and exploited rather than developed and reproduced (Thom and Zaugg, 2004). Striving to overcome the new challenges for HRM and to reduce the negative impact of HRM on employees, such as high level of stress or workrelated illness (Marriappanadar, 2012), the search for the new way of managing people has recently become increasingly significant.

In the world of today, increasing competitive pressures and the changing customer profile means that customers are the most valuable asset for companies (Weed, 2004). For this reason, competitive advantages stemming from practices designed to increase customer satisfaction, or in other words, the customer centric approach is thought to increase financial performance and profitability (Ghosh, Dutta and Stremersch, 2006). The customer centric approach has led to the rise of concepts such as customer relations management and relationship based marketing.

Environmental pollution across the globe has been increasing. For example, carbon dioxide $\left(\mathrm{CO}_{2}\right)$ reached 2,900 million metric tons in 2004 and continues to rise as evidenced by increasing concentration of $\mathrm{CO}_{2}$ in the atmosphere (UN, 2007). In Northern Africa, emission more than doubled between 1990 and 2004 increasing from 1.9 to 3.2 metric tons of $\mathrm{CO}_{2}$ per capita (Ibid, 2007). Environmental activists have been accusing business 
organizations of environmental pollution. This has led to the establishment of environmental regulations by various countries across the globe. Since financial performance is crucial to business organizations, it is important to know the effects of environmental compliance on financial performance. The effects of environmental compliance on financial performance can be understood by establishing a relationship between environmental management and financial performance.

In the dynamic and volatile environments in which most manufacturing companies operate today, flexibility of organizational factors is a valuable capability for competitive advantage (Schmenner \& Tatikonda, 2005). However, in the process of adopting the techniques of manufacturing flexibilities, firms still find it challenging to realize benefits towards performance (Anderson, 2013). Manufacturing organizational factors like flexibility towards performance due to contingencies has emerged as an important source of competitive advantage as companies seek to be responsive to changing customer demands while remaining competitive on the dimensions of cost and quality (Hallgren, Olhager, and Schroeder 2011).

Therefore, the impact of sources of competitiveness like human resource, marketing and environmental management on organizational performance was still an empirical question of significance, especially when the concept was applied to the emerging economies. Human resource management, marketing management, social responsibility and environmental management were the most crucial factors in obtaining and sustaining competitive advantage.

\subsubsection{Financial Performance}

Financial performance which assesses the fulfilment of a firm's economic goals has long been an issue of interest in managerial researches. Firm financial performance relates to the various subjective measures of how well a firm can use its given assets from primary mode of operation to generate profit.

Almajali, Alamro and Alsoub (2012) argue that there are various measures of financial performance. For instance, return on sales reveals how much a company earns in relation to its sales, return on assets explain a firm's ability to make use of its assets and return on equity reveals what return investors take for their investments. Company's financial performance can be evaluated in three dimensions. The first dimension is company's productivity, or processing inputs into outputs efficiently. The second is profitability dimension, or the level of which company's earnings are bigger than its costs. The third dimension is market premium, or the level at which company's market value is exceeds its book value (Walker, 2001).

Accounting measures are susceptible to differential accounting procedures and managerial manipulation and market-based measures, due to investor's evaluation, may not be sufficient. The advantage of market-based measures is that they can estimate the value (or the cost) of companies adopting certain strategies to be socially responsible, conditional on the existing information (Goukasian and Whitney, 2008). Measurement of firms' financial performance can be based on: profitability, liquidity, solvency, financial efficiency and repayment capacity (Fiori, Donato and Izzo, 2009). ROA represents the profitability of the firm with respect to the total set of resources, or assets, under its control (Hull and Rothenberg, 2008). Carreta and Farina (2010), argue that use of financial performance could still be justified on the grounds that it reflects what managers actually consider to be financial performance and, even if this is a mixture of various indicators like accounting profits, productivity, and cash flow.

Other than financial factors, management factors like human resources behaviour, customer satisfaction and environmental compliance also influence financial performance of a firm. In this study, financial performance was measured by profitability, market share and return on assets based on the fact that they showed the firms' ability to utilise its assets in generating wealth for shareholders (Hull and Rothenberg, 2008).

\subsubsection{Importance of Manufacturing Firms}

Manufacturing sector makes an important contribution to the Kenyan economy and currently employs 254,000 people, which represents 13 per cent of total employment with an additional 1.4 million people employed in the informal side of the industry (World Manufacturing Production, 2014). According to Awino (2011) manufacturing is an important sector in Kenya and it makes a substantial contribution to the country's economic development. It has the potential to generate foreign exchange earnings through exports and diversify the country's economy. This sector has 
grown over time both in terms of its contribution to the country's gross domestic product and employment. The average size of this sector for tropical Africa is 8 per cent.

The Kenyan manufacturing sector is considered as one of the key segments of the economy. In addition, the Kenyan vision 2030 blue print, one of the key pillars of the attainment of the objectives of the strategy is the need for the manufacturing sector to grow at the rate of 8 per cent over a period of 20 years. This can only be achieved if there is growth in the profits of the sector and this will depend upon identifying all the variables that can influence profit of a firm including the management of workers, market and environment. The inability of a firm to meet its obligations will lead to the disruption of its manufacturing process by actions such as labor strikes and blacklisting by suppliers (Kenya's Economic Outlook, 2011).

\subsubsection{Status of Performance of Manufacturing Firms}

Since independence, the Kenyan economy has remained predominantly agriculture, with industrialization taking an integral part $/$ of the country's development strategies. The industrial sector's share of monetary GDP has continued to be about $15-16 \%$ while that of manufacturing sector has stagnated at a little more than $10 \%$ over the last two decades. Manufacturing activities account for the greatest share of industrial production output and form the core of industry even if considered to grow slowly compared to industrialised countries in the world (WMP, 2014).

The manufacturing sector is the third biggest industrial sector after agriculture and transport and communication. It is the third leading sector contributing to GDP in Kenya. The sector has experienced fluctuations in level of production over the years under different financial conditions mostly contingent in nature (KPMG, 2014). Although Kenya is the most industrially developed country in East Africa, the manufacturing sector in Kenya constitutes 10 per cent of the industrial sector contribution to GDP (RoK, 2014). The growth in manufacturing industry has declined to 3.3 per cent in 2011 as compared to 4.4 per cent in the year 2010 mainly due to a challenging operating environment (KNBS, 2012). The manufacturing sector in Kenya grew at $3.5 \%$ in 2015 and $3.2 \%$ in 2014 , contributing $10.3 \%$ to gross domestic product (KNBS, 2016). On average, however, manufacturing has been growing at a slower rate than the economy, which expanded by $5.6 \%$ in 2015. This implies that the share of manufacturing in GDP has been reducing over time (KNBS, 2016). The manufacturing sector has high, yet untapped potential to contribute to employment and GDP growth. As an important sector in the overall economic growth, therefore manufacturing sector requires in depth analysis at industry as well as firm level.

\subsubsection{Nairobi Securities Exchange}

The Nairobi Securities Exchange was constituted as a voluntary association of stock brokers registered under the societies Act in 1954 and in 1991 the Nairobi Securities Exchange was incorporated under the companies Act of Kenya as a company limited by guarantee and without a share capital. Subsequent development of the market has seen an increase in the number of stockbrokers, introduction of investment banks, establishment of custodial institutions and credit rating agencies and the number of listed companies increase over time. Securities traded include, equities, bonds and preference shares (NSE, 2013).

The Nairobi Securities Exchange has classified listed companies into eleven sectors. These are; agricultural, commercial and services, telecommunication and technology, automobiles and accessories, banking, insurance, investment, manufacturing and allied, construction and allied, energy and petroleum, growth and enterprise market segment (NSE, 2013). The listed firms have their ownership structure in terms of shares which are traded at the securities market; the shares can be preferential or ordinary shares. Weidinger and Platts (2012) point out that an increase in share price denotes an increase in both a company's value and shareholders' wealth.

\subsection{Statement of the Problem}

Manufacturing firms are important for economic development as well as growth of economies. According to Awino (2011) manufacturing sector is an important sector in Kenya and it makes a substantial contribution to the country's economic development. The sector has the potential to generate foreign exchange earnings through exports and diversify the country's economy. According to KNBS (2016), manufacturing sector has been growing at a slower rate than the economy to meet the standard growth rate of the industrialised nations in the world. 
The problem facing the manufacturing sector in Kenya is the huge untapped potential resources which can contribute to employment and GDP growth and which if not checked can lead to economic crisis (Wagana \& Kabare, 2015). According to (Kenya Manufacturing Association, 2011) other challenges facing the sector includes high cost of production which is ever increasing due to poor infrastructure, regulation, tax administration and burden of government. There is also shrinking demands for locally manufactured goods due to rising poverty levels and reduced exports from general economic slump after the recent global recession

Many studies have focused on financial performance measures ignoring indicators like environment (Kargar \& Parnell 2009). It is therefore inadequate to merely analyse firm's performance by financial performance especially under today's changing operating environment (Qi, 2010). Olavarrieta and Friedman (2007) investigated the impact of three factors including the type of industry, internal factors (inventions and patents, brand names, and history of companies), and market conditions (boom, recession), on the profitability of the companies. Their results showed that innovations and patents have $\mathrm{a}$ substantial impact on profitability, market conditions also influence profitability. However, the study did not consider the human resources as a factor of financial performance. Salehi, Ghazal and Moein (2013) conducted a research entitled the relationship between social responsibility and financial performance of companies engaged in the Tehran Stock Exchange. The results showed that financial performance has no significant relationship with corporate social responsibility towards environment and employees and therefore need to involve marketing management for better performance.

In Kenya, Ahmed (2013) studied The Non- Financial Factors Influencing the Performance of Islamic Insurance in Kenya: A Case Study of Takaful Insurance of Africa where the study concluded that Legal, regulatory framework and unethical practices had a big influence on the Islamic insurance performance in Kenya. He farther proposed for an indepth finding in that employee competency but did not consider marketing concept to affect financial performance. Mochache (2015) studied Effect of Non-Financial Factors on Business Performance of Women Entrepreneurs in Service Industry in Kenya: A Case of Kisii County where the study concluded that education, type of employment, type of industry, type of company, financial background and work experience affected the business performance of women owned enterprises in the service industry in Kenya. The study did not clearly bring out the effect of environmental and marketing factors to influence manufacturing firms performance

However, the contribution of Olavarrieta and Friedman (2007), Salehi et al (2013), Ahmed (2013) and Mochache (2015) to the development of financial performance of listed companies in developing countries like Kenya is still unclear since this has not been systematically documented. This study was therefore to bridge this gap by determining the effects of human resource, marketing and environmental management on financial performance of listed manufacturing companies. It answered the question, what were the effects of human resource, marketing and environmental management on financial performance of manufacturing firms listed at Nairobi Securities Exchange market in Kenya?

\subsection{Objectives of the Study}

\subsubsection{General Objective}

To establish the effects of human resource, marketing and environmental management on financial performance of manufacturing firms listed at Nairobi Securities Exchange market in Kenya.

\subsubsection{Specific Objectives}

I. To determine the effect of human resource management on financial performance of manufacturing firms listed at Nairobi Securities Exchange market in Kenya.

II. To examine the effect of marketing management on financial performance of manufacturing firms listed at Nairobi Securities Exchange market in Kenya.

III. To evaluate the effect of environmental management on financial performance of manufacturing firms listed at Nairobi Securities Exchange market in Kenya.

\subsection{Research Questions}

I. What is the effect of human resource management on financial performance of manufacturing firms listed at Nairobi Securities Exchange market in Kenya?

II. How does marketing management affect financial performance of manufacturing firms 
listed at Nairobi Securities Exchange market in Kenya?

III. Which effect does environmental management have on financial performance of manufacturing firms listed at Nairobi Securities Exchange market in Kenya?

\subsection{Significance of the Study}

To the listed companies' managers, the study identifies the modes of sustainability in the operating environment for implementation of business process and problem solution while potential investors and business persons will be provided with information on some of the critical challenges they will have to face hence prepare them well enough to meet this challenges. Businessmen will be able to use the information to improve the relationship between the business and the customers as well as the workers.

The results of the study will also be useful to the government in formulating policies and developing regulatory frameworks for manufacturing listed companies, especially where quality standardization is concerned. The study will increase the body of knowledge in this area and stimulate further research in the manufacturing sector. Businessmen, scholars and academicians will find it useful for enhancing their understanding on the subject of study and beef up their knowledge on manufacturing firms and will add to the literature on business process improvement and identify areas for further study.

\subsection{Scope of the Study}

The study was to identify the effects of human resource, marketing and environmental management on financial performance of manufacturing firms listed at the NSE. The study was carried out in manufacturing firms listed at the Nairobi Securities Exchange Market in Kenya and the study covered duration of five years (2011-2015). The listed manufacturing firms for study were majorly established in Nairobi and other parts of the country. The major issues that were covered included human resource, marketing and environmental management. The study used both primary and secondary data. The population of the study was the ten manufacturing firms listed at the NSE in Kenya. This targeted the management staff of NSE listed manufacturing firms in Kenya. Primary data was collected through questionnaires administered to the selected respondents while secondary data, that was, financial data was collected from annual financial accounts for past five years. Chi- Test was carried out to find out whether the dependent variable and independent variables were positively related, negatively related or there was no relation at all between the variables.

\subsection{Limitation of the Study}

The researcher expected challenges in accessing information which was not readily available especially from the senior management due to fear of leakage of company information to the public. Some were suspicious of the researcher's intentions and were not cooperative, but the researcher assured them of confidentiality on information collected and no names were to be mentioned. Introduction letter from University, permit letter from National Commission for Science, Technology and Innovation were provided during data collection process for identification and clarification of the aim of data collection.

\subsection{Organisation of the Study}

This research proposal had three chapters. Chapter One give a background to the research, which highlighted human resource, marketing and environmental management, financial performance, manufacturing firms and stock exchange market. The problem statement highlighted the gap in knowledge on the influence of human resource, marketing and environmental management on financial performance of listed manufacturing firms at Nairobi Securities Exchange in Kenya. The section further detailed the study objectives, the research questions and the significance of the study to yarious stakeholders.

Chapter Two addressed the theoretical and empirical review for the study which provided a contextual background for the study. The section provided theories of human resource, marketing and environmental management in relation to financial performance overview. Literature on human resource, marketing and environmental management and summary of chapter two is reviewed in the last section.

Chapter Three described the research methodology used to test the hypotheses and answer research questions established in Chapter One. It also included the research design, target population, sampling design and sample size, data collection instruments, techniques of analysis and presentation and ethical consideration. 
Chapter Four contained results of response rate, descriptive findings and inferential statistics. This chapter outlined the analysis and presentation of data on the effects of human resource, marketing and environmental management on financial performance of manufacturing companies listed at Nairobi Securities Exchange market in Kenya.

Chapter five highlighted on the summary of the findings, the discussion, conclusions, recommendations of the study based on the objective of the study and suggestions for further findings.

\section{LITERATURE REVIEW}

\subsection{Introduction}

The chapter focuses on theoretical, empirical literature, summary of literature review and research gap and conceptual framework of the study. It contains theories and literature review on studies that have been done in the past on human resource, marketing and environmental management and financial performance. The chapter begins with theoretical review which consists of theories related to human resource, marketing and environmental management and their relation to financial performance followed by a summary of literature review and research gap and conceptual framework of the study.

\subsection{Theoretical Review}

Previous studies have used four main theories to explain the relationship among human resource, marketing and environmental management and listed company's financial performance. These are: Social network theory, the theory of firm and Stakeholder theory and Agency theory perspectives.

\subsubsection{Social Network Theory}

The theory was proposed by sociologist Anthony Giddens in 1979. This theory focuses on a firm's position, interaction, connectedness and reward structure within its network, all of which are highly dependent on their setting or context. In addition, social network constructs of density and centrality push researchers to consider the impact of stakeholders who do not have direct relationships with the focal firm but who nevertheless affect how the firm behaves (Rowley, 1997).

Gouldson (2004) illustrated how social network theory can be applied to trace the effects among multiple stakeholders in a network of enhanced access to information on firms' environmental impacts. He analyzed how increased access to information from pollution release and transfer registers influenced governance through a complex web of social relations among regulators, industry and other stakeholder groups. Businesses could test out new marketing methods and ideas easily online and get instant feedback from their customers. For example, Amazon has been the largest social science laboratory by testing many models of consumer purchase behavior (Contractor, 2009).

Social network theory creates social ties between employees and management hence leading to unpredictable consequences as a result of status employee has in the social network hence varying human resource management activities (Sozen, 2012). Human resource and marketing management require social relationship of individuals and groups for better performance and the human behavior is the driving force to environmental changes.

\subsubsection{Theory of the Firm}

The new theory of the firm was founded by Professor Michael Jensen in 1980 according to Bratton (1989). The theory of the firm began with the emergence of economic science in the $18^{\text {th }}$ century, which took as its main reference the study of Adam Smith on the origins of the wealth of nations. Throughout the $20^{\text {th }}$ century, several studies, in particular that of Coase (1937) on transaction costs, enriched and developed the theory of the firm. As with other microeconomic theories, the theory of the firm establishes profit maximization as its goal. However, profit maximization requires a more specific definition, such as if it is accounting or economic and short or longterm, among other characteristics. Jensen (2001) clarifies that, for economists, the objective of the firm should be to seek maximization of the long-term market value, resulting from the ability to generate cash over time. Maximizing the company's value maximizes the shareholder's wealth. Wright, Mukherji and Kroll (2001), argued the need to connect the HRM literature to knowledge-based and capability theories of the firm.

\subsubsection{Stakeholder Theory}

Stakeholders' theory was founded by Boka. It was originally detailed by Freeman in the book Strategic Management in 1984: A Stakeholder Approach, and identifies and models the groups which are stakeholders of a corporation, and both describe and 
recommends methods by which management can give due regard to the interests of those groups. The main framework for stakeholder theory has normally been attributed to the work of Freeman from 1984 (Barnett, 2007). According to Coombs and Gilley (2005), the most employed definition for the term stakeholder in the literature is that proposed by Freeman (1984) in which the stakeholder is any individual or group that may affect the achievement of the organization goals or that is affected by the process of searching for these objectives.

The principles of stakeholder theory are in keeping with the pluralist assumptions that labour is more than a commodity or factor of production, that there exists inequality of bargaining power between employers and employees in imperfect labour markets, that employers and employees are likely to have differing goal and as such there is likely to be conflict between the parties, and that employee voice is important in a democratic society (Budd, 2004). While marketing research has mainly focused on single stakeholder relationships, the idea of multiple stakeholder relationships to achieve maximum firm performance has been evolving slowly over the last decade (Sen, Bhattacharya and Korschun, 2006). The definition of marketing debate continued, with concern that deleting the stakeholder term was a setback that required explanation (Gundlach and Wilkie 2010).

Employees who define the HRM in the manufacturing firms have interest in the performance emanating from their behavior hence HRM has direct link with organisation, the same to suppliers and consumers depend on the firm and form greater part of manufacturing firm hence the need to link marketing management to performance of the firm. The law enforcers concerning environment in which the firm operates also influence its direction.

\subsubsection{Agency theory}

The first scholars to propose, explicitly, that a theory of agency be created, and to actually begin its creation, were Stephen Ross and Barry Mitnick in the early, 1970s. According to the agency theory; the expected costs of firm's social - environmental responsibility is likely to outweigh the resulting benefits and hence firm social performance is expected to have a negative impact on firm profitability, (Friedman 1970). Auperlle, Carrol and Hartfield. (1985) explain this theory by arguing that; those firms that spend money on some pollution control instrument will incur costs that may affect their price and thus profitability whilst other competitors do not do this on the basis that it is the government's responsibility. The main argument in agency theory as related to environmental regulations is that, corporate environmental responsibility can be explained as an agency problem between firm's management and shareholders. In short the agency theory suggests that, compliance to environmental regulations should have negative effect on the financial performance.

With regard to human nature, Agency Theory's assumption of self-interest relates to the fact that in case of unanticipated events, actors will each behave in the best interest of their companies (Logan, 2000), or perhaps functional area. Due to bounded rationality of the players and the complexity of contractual situations, the Agent's decisions and decisions which maximize the welfare of the Principal frequently conflict (Wright, Mukherji \& Kroll, 2001), as a result of which agency costs accrue. Heide (2003) puts it, the "invisible hand" of the market through management expertise, and the "visible hand" of the internal organization through marketing's ability to evaluate whether the supplier meets its needs.

The consequences of the counter positions were obvious in empirical studies that analyzed human resource, marketing and environmental management. More specifically, these studies revealed that there was an alignment of marketing performance with financial performance, according to the theory of the firm, human resource management and social responsibility, according to stakeholder theory and environmental management, according to the social network and agency theories.

\subsection{Empirical Review}

The section reviewed the literature pertaining human resource, marketing and environmental management in relation to financial performance of the listed manufacturing firms in Kenya.

\subsubsection{Human Resource Management and Financial Performance}

The impact of Human resource management practices on financial performance had been the subject of much attention over many years. Over the years, researchers have suggested many human resource management practices that have the potential to improve and maintain organizational performance 
Ahmad and Schroeder (2003). Many researchers investigated the effect of the HRM practices on firm performance. Their research results show that human resource performance has statistical influence on the financial performance (Batt 2002). The studies based their facts on firm growth through proper selection, training and compensation of employees but failed to address the growth factor of employees like career path and succession and financial performance.

Preuss (2003) studied effect of high performance work systems on quality health care in Australia and found out positive relationship between high performance work systems and quality healthcare that is mediated by HRM outcome like psychological empowerment. The study did not consider the human resource growth and development through training and career path to improve financial performance. Liao (2005) study of effect of human resource control and business strategy on firm performance where he found that HRM control is positively related to firm performance. The study did not specifically relate the human resource control to financial performance and also enriching the employees with skills influence financial performance.

Wanyama and Mutsotso (2010) studied Relationship between capacity building and employee productivity on performance of commercial banks in Kenya where the empirical research evidence showed that indeed capacity building and employee productivity has a positive correlation on organizational performance. Biswas, Cascio and Boudreau (2013) estimates cost of lost productive time due to low morale of remaining employees as the aggregate time lost per day of the work group multiplied by wages plus benefits of a single employees and then multiplied by number of days. Vance (2009) measures employee productivity using factors like production, billable hours, ill rate, and degree of supervision, among others. The studies of Wanyama and Mutsotso (2010), Biswas, Cascio and Boudreau (2013) and Vance (2009) did not address efficient recruitment and selection and succession to improve financial performance in manufacturing firms in Kenya.

Gaudine and Saks (2001) conducted a study in Canada which sought to test the influence of employee absenteeism in the organisation. Absenteeism was found highest among the health care sector and the social assistance workers. Adegboyega, Dele and Ayodeji (2015) studied effect of absenteeism on corporate performance: a case study of Cadbury Nigeria plc, ikeja, lagos state, Nigeria. The conclusion was that absenteeism significantly affects corporate performance. This result was confirmed based on the results of the analysis of the determinant variables which showed that absenteeism reduces the level of organizational productivity, profitability, quality service delivery and promptness of meeting customers' demand. These studies did not look at the issues that address the absenteeism like career path and development of employees which influence financial performance of manufacturing firms.

Kimosop (2007) presented the results of the effects of labour turnover on organizations' performance in Kenya private security firms. The researcher used a case study of Future Force Security Firm. The study findings indicated that the factors that influenced labour turnover were related to the working conditions and they included: low pay, long working hours, misconduct, and lack of career prospects. Similarly, Alam and Shahi (2012) study sought to find out the job satisfaction, motivation and turnover factors of medical promotion officers based in Khulna City in Bangladesh. The study established that their turnover tendency was high. The respondents in their study were dissatisfied with the working conditions which were characterized by job insecurity, poor social status, working load, visit to retailers' shops, sales target, no room for family, not getting the retirement benefit and not getting the family insurance support. Githinji (2014) study on the effect of staff turnover on financial performance of private security firms in Kenya concluded that staff turnover directly negatively affects the financial performance of private security firms in Kenya through its impact on recruitment costs and lost productivity. These studies did not deal with HRM retention practices like training and development and succession which affect financial performance of manufacturing firms in Kenya.

\subsubsection{Marketing Management and Financial Performance}

Marketing is the management concept responsible for identifying, anticipating and satisfying customer requirements profitably. The marketing concept is the philosophy that an organization should provide products that satisfy customer needs through a coordinated set of activities that also allow the organization to achieve its goals (Baines, Fill and 
Page, 2008). The role of marketing is satisfying the customer hence meeting their expectations. The consequences of not meeting customer expectations may include: a reduction in sales and increase in a number of dissatisfied customers, cost associated with managing defective goods and services, reputation risk and cost associated with defending cases brought against the company in court (Dibb, Simkin, Pride, Ferrell, 2006).

A number of studies have been conducted to examine the impact of marketing performance on financial performance. Emphasizing responsiveness, meeting the customer's needs through providing pre-sale, transactional, and post-sale services can improve sales volume and financial performance (Li, 2000). Kanning and Bergmann (2009) on their study stated that a positive relationship exists between customer satisfaction and financial performance and distinguish customer satisfaction differently using the confirmation/disconfirmation paradigm model. They further note that, when customers' expectations are fulfilled, the result is satisfaction and if not, dissatisfaction occurs. Kombo (2015) studied customer satisfaction in Kenyan banking industry and concluded that high prices of products and services are the most important factor of dissatisfaction. It was also found that satisfied and dissatisfied customers in Kenya use the services of two banking products while satisfied and dissatisfied Kenyan customers statistically use only the services of one bank. The studies of Li (2000), Kanning and Bergmann (2009) and Kombo (2015) lacked the marketing functions like planning, analysis and control which influence financial performance of manufacturing companies in Kenya leading to in-depth research on this study.

Robert and Dowling (2002) confirmed that firms with better reputation sustain superior performance for a longer period and have an easier time attaining competitive advantage using the Fortune's American Most Admired Corporations report from 1994 to 1998. Owino (2013) examined service quality, corporate image and customer satisfaction in public universities in Kenya. They established that corporate image had a significant positive influence on customer satisfaction in Public Universities in Kenya. While the study brought some insight into the role of corporate image and satisfaction, they did not focus on financial measures of performance in relation to marketing functions, hence leaving a knowledge gap.
Lee and Roh (2012) studied effects of corporate reputation on firm's financial performance and found out that corporate reputation was positively related to financial performance but the study in corporate reputation lacked an in depth knowledge about marketing functions and their effects on financial performance of manufacturing firms. By extension, the study of Beck, Cull, Fuchs, Getenga and Randa (2010) on effect of market share on financial performance of organisation and found the positive relation with more efficient firms gaining greater market share, which resulted in a more concentrated market. The study concentrated on market share and filed to address marketing control, analysis and planning effect on performance of manufacturing firms.

\subsubsection{Environmental Management and Financial performance.}

According to Murphy (2012) manufacturing industries are increasingly being pressurized to have eco-friendlier policies. Consequently, many governments have incorporated environmental policies and regulation frameworks in their administration. As a result, more eco friendly activities are being embraced by various industries such as the integration of design for the environment into their products and the use of sustainable distribution practices. Manufacturers therefore must appreciate the requirements and ensure that their products conform to the regulations. The study did not explain how waste management influencing financial performance of manufacturing firms was applied.

Filbeck and Gorman (2004) studied the relationship between the environmental performance and financial performance of public utilities and found out negative relationship between environmental performances and attributed the result to usage of electric utility industry and use of recent period information. However, most prevalent approaches to environmental management are so detached from business that companies fail to achieve the greatest opportunities for society. This limitation implies that managers must develop highly focused and effective environmental actions after having identified which environmental issues matter most to the firm. By doing so, the firm can increase its own profit and strengthen its long-term competitiveness, as well as making a meaningful environmental impact and thereby achieving a winwin situation through the creation of the synergistic value known as shared value (Ditlev-Simonsen \& 
Midttun, 2011). The work of Filbeck and Gorman (2004) and Ditlev-Simonsen \& Midttun (2011) failed to give details of the planning of environment and recycling of wastes on financial performance of the manufacturing companies in Kenya.

Studies on the relationship between environmental regulations and financial performance do not provide similar results. There are studies which suggest a positive relationship, others negative relationship and even some of them suggest that there is no significant relationship. Dowel, Hart and Yeung (2000) argues that firms that adopt single stringent environmental standards worldwide have higher market valuations than firms that do not adopt such standards. A study carried out by Zhu, Sarkis and Lai (2006) concluded that to stay competitive in the market, managers should improve their environmental compliance that has been setup by the authority, address the environmental concern of the customer and mitigate the environmental impact of their products and services. The studies only concentrated on environmental regulation compliance and failed to consider impact of waste management and proper planning performance of manufacturing firms in Kenya.

A positive relationship between environmental regulations and financial performance is further supported by other empirical studies. Schneitz and Epstien (2005) documented less negative reaction from the stock market after environmental crises. A negative relationship between environmental compliance and financial performance has also found support among prior research works. Naila (2013) studied the effect of environmental regulations on financial performance in Tanzania which was a survey of manufacturing companies quoted on the Dar es Salaam stock exchange and concluded that environmental compliance had no significant effect on the financial performance of the listed manufacturing firms. These findings were consistent with the theory of firm perspective which suggests that, the environmental compliance has no effect on the financial performance but no more in-depth discussion pertaining environmental planning and recycling of wastes that affects financial operations of the manufacturing firms. Maru, Chepwony and Menjo (2012) studied recycling of waste as a determinant of financial performance of small and medium enterprises in Eldoret Town, Kenya and concluded that recycling as one of waste recycling strategies shows it affects financial performance of SMEs. The study did not capture manufacturing firm operations and also failed to incorporate compliance to regulations effect on performance of manufacturing firms.

\subsection{Summary of Literature Review and Research Gap}

The literature reviewed showed that manufacturing firms in the emerging markets were affected by various factors. The determinants of manufacturing firm's financial performance was mostly based on the human resource, marketing and environmental management among other factors. There was considerable work done by researchers on the effects of factors such as human resource, marketing and environmental management on listed manufacturing firm's financial performance in developed countries. Based on the literature review, the relationship between these factors and financial performance could be positive, negative, or neutral. For example, it was noted that possible measures for operational performance were; selection and recruitment, training and development, succession and career path, marketing planning, market analysis and evaluation, marketing control, laws and regulation compliance, recycling of wastes and environmental planning. The theoretical review covered theories concerning the study including social network, theory of the firm, stakeholder theory and agency theory.

However very little research had been conducted in emerging markets for instance Africa where most manufacturing firms' financial performance and growth had been threatened by these factors. Moreover, there were contrasting findings in developed and developing countries in regard to the effect of various factors on financial performance of listed manufacturing firms hence a need to conduct a further research. It was from the above identified gaps that the researcher seeked to conduct a study to determine human resource, marketing and environmental management factors affecting financial performance of manufacturing firms listed at the NSE in Kenya. 
Table 2.1 Summary of Literature Review and Research Gap

\begin{tabular}{|c|c|c|c|c|c|c|}
\hline Author & Title & Methodology & Findings & Recommendation & Gap & Gap Filled \\
\hline $\begin{array}{l}\text { Wanyama } \\
\text { and } \\
\text { Mutsotso }\end{array}$ & $\begin{array}{c}\text { Effects of } \\
\text { capacity } \\
\text { building and } \\
\text { employee } \\
\text { productivity } \\
\text { on financial } \\
\text { performance } \\
\text { of } \\
\text { commercial } \\
\text { banks in } \\
\text { Kenya }\end{array}$ & & $\begin{array}{l}\text { Employee } \\
\text { productivity } \\
\text { and capacity } \\
\text { building is } \\
\text { positively and } \\
\text { significantly } \\
\text { related to } \\
\text { financial } \\
\text { performance }\end{array}$ & $\begin{array}{l}\text { Managers in the } \\
\text { banking sector and } \\
\text { academicians to } \\
\text { encourage } \\
\text { employee } \\
\text { motivation, } \\
\text { satisfaction and } \\
\text { future research. }\end{array}$ & $\begin{array}{c}\text { Not } \\
\text { captured } \\
\text { recruitment } \\
\text { and } \\
\text { selection } \\
\text { and career } \\
\text { path }\end{array}$ & $\begin{array}{l}\text { Recruitmen } \\
t \text { and } \\
\text { selection } \\
\text { and career } \\
\text { path } \\
\text { studied }\end{array}$ \\
\hline $\begin{array}{l}\text { Gaudine } \\
\text { and Saks }\end{array}$ & $\begin{array}{l}\text { Influence of } \\
\text { employee } \\
\text { absenteeism } \\
\text { on } \\
\text { organization } \\
\text { in Canada }\end{array}$ & & $\begin{array}{c}\text { High } \\
\text { absentism } \\
\text { among health } \\
\text { care and social } \\
\text { assistant }\end{array}$ & & $\begin{array}{l}\text { Not covered } \\
\text { Training } \\
\text { and } \\
\text { developmen } \\
\text { t, selection } \\
\text { and } \\
\text { recruitmeny }\end{array}$ & $\begin{array}{c}\text { Covered } \\
\text { Training } \\
\text { and } \\
\text { developme } \\
\text { nt, selection } \\
\text { and } \\
\text { recruitmeny }\end{array}$ \\
\hline Kimosop & $\begin{array}{l}\text { Effects of } \\
\text { labour } \\
\text { turnover on } \\
\text { organization } \\
\text { performance } \\
\text { in Kenya } \\
\text { private } \\
\text { security firms }\end{array}$ & $\begin{array}{c}\text { Self- } \\
\text { administered } \\
\text { questionnaire } \\
0 \\
0\end{array}$ & $\begin{array}{l}\text { Labour } \\
\text { turnover } \\
\text { positively } \\
\text { related to } \\
\text { organizational } \\
\text { performance } \\
\text { esearch }\end{array}$ & $\begin{array}{l}\text { ournal } \\
\text { entific } \\
\text { nd }\end{array}$ & $\begin{array}{c}\text { Did not } \\
\text { cover } \\
\text { training and } \\
\text { developmen } \\
t \text { and } \\
\text { selection } \\
\text { and } \\
\text { recruitment }\end{array}$ & $\begin{array}{l}\text { Did not } \\
\text { cover } \\
\text { training and } \\
\text { developme } \\
\text { nt and } \\
\text { selection } \\
\text { and } \\
\text { recruitment }\end{array}$ \\
\hline $\begin{array}{l}\text { Alam and } \\
\text { Shahi }\end{array}$ & $\begin{array}{l}\text { Effects of job } \\
\text { satisfaction, } \\
\text { motivation } \\
\text { and turnover } \\
\text { on medical } \\
\text { officers' } \\
\text { promotions in } \\
\text { Kulna City in } \\
\text { Bangladesh }\end{array}$ & $\begin{array}{l}\text { Five point based } \\
\text { likert scale }\end{array}$ & $\begin{array}{l}\text { Job } p m \\
\text { satisfaction, } \\
\text { motivation } \\
\text { and turnover } \\
\text { affected } \\
\text { medical } \\
\text { officers } \\
\text { promotion }\end{array}$ & $\begin{array}{l}\text { Removal of } \\
\text { restraing forc } \\
\text { factors }\end{array}$ & $\begin{array}{l}\text { Not studied } \\
\text { selection } \\
\text { and } \\
\text { recruitment } \\
\text { training }\end{array}$ & $\begin{array}{l}\text { Covered } \\
\text { selection } \\
\text { and } \\
\text { recruitment } \\
\text { and training }\end{array}$ \\
\hline Githinji & $\begin{array}{l}\text { Relationship } \\
\text { between } \\
\text { workers' } \\
\text { turnover on } \\
\text { financial } \\
\text { organizationa } \\
1 \text { performance } \\
\text { of Private } \\
\text { Security } \\
\text { Firms in } \\
\text { Kenya }\end{array}$ & $\begin{array}{c}\text { Structured } \\
\text { questionnaires } \\
\text { used }\end{array}$ & $\begin{array}{l}\text { Staff turnover } \\
\text { was } \\
\text { significantly } \\
\text { and negatively } \\
\text { related to } \\
\text { performance } \\
\text { of the } \\
\text { organisation. }\end{array}$ & $\begin{array}{l}\text { Investment in staff } \\
\text { development and } \\
\text { retention of core } \\
\text { talent }\end{array}$ & $\begin{array}{l}\text { Not studied } \\
\text { selection, } \\
\text { recruitment, } \\
\text { training and } \\
\text { career path }\end{array}$ & $\begin{array}{c}\text { Covered } \\
\text { selection, } \\
\text { recruitment } \\
\text {, training } \\
\text { and career } \\
\text { path }\end{array}$ \\
\hline Preuss & $\begin{array}{l}\text { Effect of high } \\
\text { performance } \\
\text { work systems } \\
\text { on quality }\end{array}$ & $\begin{array}{l}\text { Used structured } \\
\text { questionnaires } \\
\text { to collect data }\end{array}$ & $\begin{array}{l}\text { High } \\
\text { performance } \\
\text { work system } \\
\text { related to } \\
\end{array}$ & $\begin{array}{l}\text { Provide employee } \\
\text { with knowledge } \\
\text { and skills }\end{array}$ & $\begin{array}{l}\text { Not covered } \\
\text { selection } \\
\text { and } \\
\text { recruitment }\end{array}$ & $\begin{array}{l}\text { Covered } \\
\text { selection } \\
\text { and } \\
\text { recruitment }\end{array}$ \\
\hline
\end{tabular}


International Journal of Trend in Scientific Research and Development (IJTSRD) ISSN: 2456-6470

\begin{tabular}{|c|c|c|c|c|c|c|}
\hline & $\begin{array}{l}\text { health care in } \\
\text { Australia }\end{array}$ & & $\begin{array}{l}\text { quality of } \\
\text { health care }\end{array}$ & & and training & and training \\
\hline Kombo & $\begin{array}{c}\text { Effects of } \\
\text { customer } \\
\text { satisfaction of } \\
\text { financial } \\
\text { performance } \\
\text { of } \\
\text { commercial } \\
\text { banks in } \\
\text { Kenya }\end{array}$ & $\begin{array}{l}\text { Questionnaire } \\
\text { survey used }\end{array}$ & $\begin{array}{l}\text { Found that } \\
\text { customer } \\
\text { satisfaction } \\
\text { positively } \\
\text { affect } \\
\text { financial } \\
\text { performance }\end{array}$ & $\begin{array}{l}\text { Policy making and } \\
\text { possible areas for } \\
\text { research }\end{array}$ & $\begin{array}{l}\text { The study } \\
\text { did not } \\
\text { capture } \\
\text { planning, } \\
\text { analysis and } \\
\text { control in } \\
\text { marketing }\end{array}$ & $\begin{array}{l}\text { Captured } \\
\text { planning, } \\
\text { analysis } \\
\text { and control } \\
\text { in } \\
\text { marketing }\end{array}$ \\
\hline Owino & $\begin{array}{c}\text { Effect of } \\
\text { service } \\
\text { quality, } \\
\text { corporate } \\
\text { image and } \\
\text { customer } \\
\text { satisfaction } \\
\text { performance } \\
\text { of public } \\
\text { universities in } \\
\text { Kenya }\end{array}$ & $\begin{array}{c}\text { Cross sectional } \\
\text { sample survey } \\
\text { used to collect } \\
\text { data }\end{array}$ & $\begin{array}{l}\text { Established } \\
\text { that corporate } \\
\text { image had a } \\
\text { significant } \\
\text { positive } \\
\text { influence on } \\
\text { customer } \\
\text { satisfaction in } \\
\text { Public } \\
\text { Universities in } \\
\text { Kenya }\end{array}$ & $\begin{array}{c}\text { Investment in } \\
\text { services reliability } \\
\text { and cororate brand }\end{array}$ & $\begin{array}{l}\text { Not capture } \\
\text { marketing } \\
\text { planning, } \\
\text { analysis and } \\
\text { control }\end{array}$ & $\begin{array}{l}\text { Captured } \\
\text { marketing } \\
\text { planning, } \\
\text { analysis } \\
\text { and control }\end{array}$ \\
\hline $\begin{array}{l}\text { Schneitz } \\
\text { and } \\
\text { Epstien }\end{array}$ & $\begin{array}{c}\text { Effect of } \\
\text { environmenta } \\
1 \text { crisis on } \\
\text { financial } \\
\text { performance } \\
\text { of firms listed } \\
\text { in stock } \\
\text { market }\end{array}$ & $\begin{array}{c}\text { Survey } \\
\text { questionnaire } \\
\text { used for data } \\
\text { collection } \\
0\end{array}$ & $\begin{array}{l}\text { Revealed a } \\
\text { negative } \\
\text { relationship } \\
\text { environmental } \\
\text { crisis and } \\
\text { performance } \\
\text { evelopm }\end{array}$ & $\begin{array}{l}\text { Mangers to } \\
\text { prepare and } \\
\text { mobilise the } \\
\text { workforce to curb } \\
\text { nd crisis }\end{array}$ & $\begin{array}{l}\text { Not } \\
\text { captured } \\
\text { waste } \\
\text { managemen } \\
t \text { and } \\
\text { regulation in } \\
\text { environment }\end{array}$ & $\begin{array}{c}\text { Captured } \\
\text { waste } \\
\text { managemen } \\
t \text { and } \\
\text { regulation } \\
\text { in } \\
\text { environmen } \\
t\end{array}$ \\
\hline Naila & $\begin{array}{c}\text { Relationship } \\
\text { between } \\
\text { environmenta } \\
1 \text { compliance } \\
\text { and financial } \\
\text { performance } \\
\text { in Tanzania } \\
\text { stock } \\
\text { exchange }\end{array}$ & $\begin{array}{l}\text { Survey used to } \\
\text { obtain data for }\end{array}$ & $\begin{array}{l}\text { Concluded } \\
\text { that there was } \\
\text { no significant } \\
\text { relationship } \\
\text { between } \\
\text { environment } \\
\text { compliance } \\
\text { and financial } \\
\text { performance }\end{array}$ & & $\begin{array}{l}\text { Not studied } \\
\text { waste } \\
\text { recycling } \\
\text { and } \\
\text { environment } \\
\text { al planning }\end{array}$ & $\begin{array}{l}\text { Studied } \\
\text { waste } \\
\text { recycling } \\
\text { and } \\
\text { environmen } \\
\text { tal planning }\end{array}$ \\
\hline $\begin{array}{l}\text { Maru, } \\
\text { Chepkwo } \\
\text { ny and } \\
\text { Menjo }\end{array}$ & $\begin{array}{l}\text { Relationship } \\
\text { between } \\
\text { recycling of } \\
\text { wastes and } \\
\text { financial } \\
\text { performance } \\
\text { of SMEs in } \\
\text { Eldoret }\end{array}$ & $\begin{array}{l}\text { Five point likert } \\
\text { scale } \\
\text { questionnaire } \\
\text { and structured } \\
\text { interview }\end{array}$ & $\begin{array}{l}\text { Positive and } \\
\text { significant } \\
\text { relationship } \\
\text { between } \\
\text { recycling of } \\
\text { wastes and } \\
\text { financial } \\
\text { performance } \\
\text { of SMEs in } \\
\text { Kenya. }\end{array}$ & $\begin{array}{l}\text { Awareness to be } \\
\text { done on waste } \\
\text { recycling to } \\
\text { reduce cost of } \\
\text { management }\end{array}$ & $\begin{array}{l}\text { Did not } \\
\text { capture } \\
\text { compliance } \\
\text { to } \\
\text { environment } \\
\text { al regulation } \\
\text { and } \\
\text { environment } \\
\text { al planning }\end{array}$ & $\begin{array}{c}\text { Captured } \\
\text { compliance } \\
\text { to } \\
\text { environmen } \\
\text { tal } \\
\text { regulation } \\
\text { and } \\
\text { environmen } \\
\text { tal planning }\end{array}$ \\
\hline
\end{tabular}

Source: Author (2016) 


\subsection{Conceptual Framework}

Conceptual framework defines the relationship between independent and dependent variables in a given project study. The study sought to determine relationship between human resources, marketing and

environmental management on financial performance of the manufacturing firms listed at NSE in Kenya. The independent variables in the study included; human resource, marketing and environmental management. The dependent variables in this study included; profitability, market share and return on assets. The intervening variables in the study were; education level of the staff, consumer satisfaction and social responsibility, which had influence on the financial performance of manufacturing firms listed at NSE in Kenya. The variables are presented in conceptual framework Figure 2.

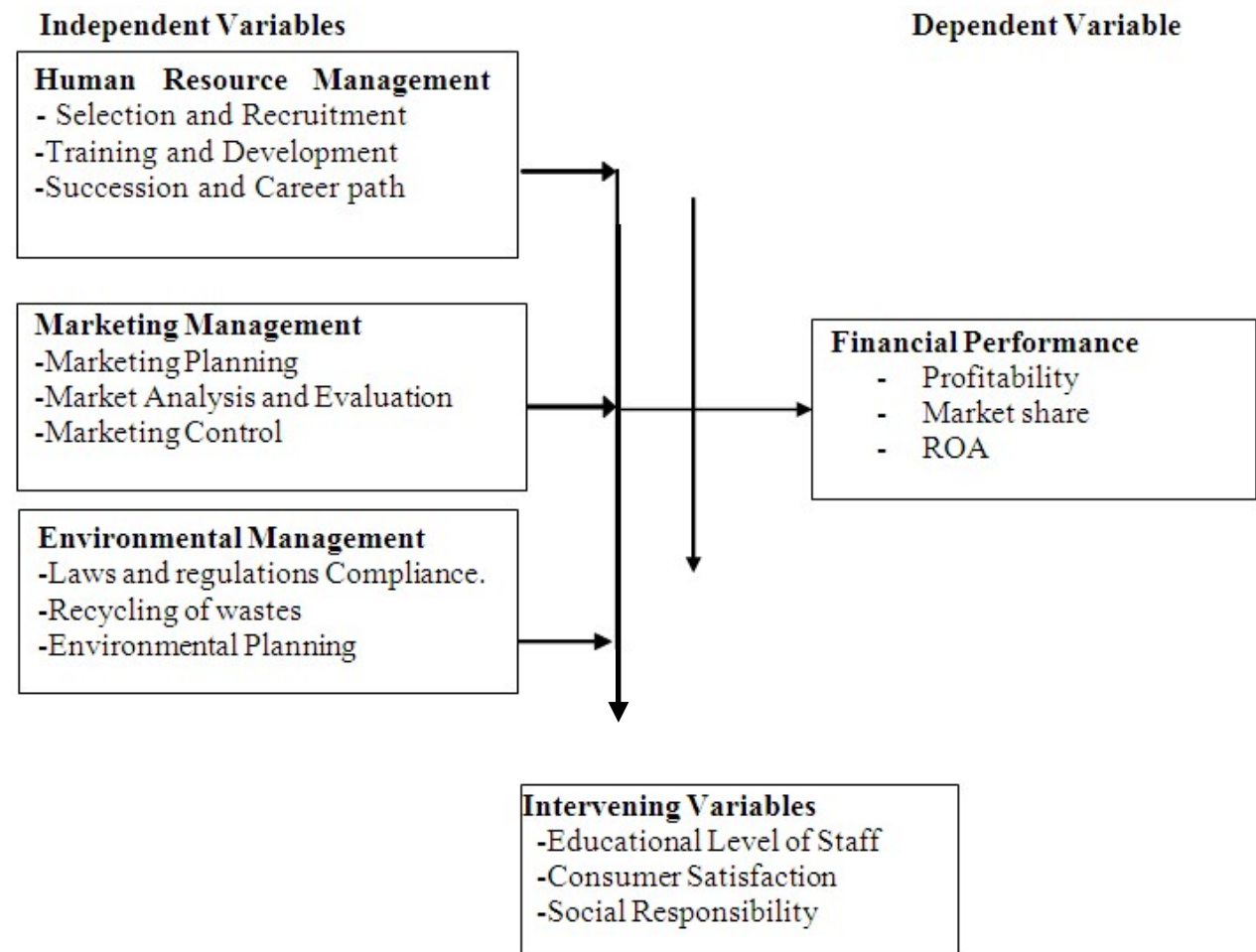

Figure 2.1: Conceptual Framework

\section{Source: Author (2016)}

\section{RESEARCH METHODOLOGY}

\subsection{Introduction}

This chapter outlined the general methodology used to conduct the study. It specified the research design, target population, sampling design, data collection method and instruments, and data analysis and interpretation.

\subsection{Research Design}

The study used descriptive research design. Research design is the plan and structure of investigation so conceived as to obtain answers to research questions. Descriptive research design was deemed fit for this study since it allowed the collection of data from a sizable population in a highly economical way. A descriptive research design is used when data are collected to describe persons, organizations, settings or phenomena. The design also has enough provision for protection of bias and maximized reliability
(Mugenda \& Mugenda, 2012). Therefore, the descriptive survey was deemed the best strategy to fulfill the objectives of this study. Generally, this design dealt with incidences of distribution and relationships of variables.

\subsection{Target Population}

Target population are those people, events or records that contain the desired information and can answer the measurement questions (Cooper and Schindler, 2011). The target population for this study consisted of all the listed manufacturing firms composed of ten companies in the NSE from 2011 to 2015.The target population was the staff of listed manufacturing firms at the NSE. There were ten manufacturing firms listed at the NSE and the study targeted staff in each and every listed manufacturing companies in NSE as shown in Table 3.1 
International Journal of Trend in Scientific Research and Development (IJTSRD) ISSN: 2456-6470

Table 3.1 Target Population

\begin{tabular}{|c|c|}
\hline $\begin{array}{c}\text { NSE Listed } \\
\text { Manufacturing Firms }\end{array}$ & $\begin{array}{c}\text { Population (No. } \\
\text { Of Workers) }\end{array}$ \\
\hline B.O.C Kenya Ltd & 226 \\
\hline $\begin{array}{c}\text { British American Tobacco } \\
\text { Kenya Ltd }\end{array}$ & 500 \\
\hline Carbacid Investments Ltd & 69 \\
\hline East African Breweries Ltd & 827 \\
\hline Mumias Sugar Co. Ltd & 1,795 \\
\hline Unga Group Ltd & 425 \\
\hline Eveready East Africa Ltd & 205 \\
\hline Kenya Orchards Ltd & 102 \\
\hline A.Baumann CO Ltd & 100 \\
\hline Flame Tree Group Holdings & 160 \\
\hline Total & 4,409 \\
\hline
\end{tabular}

Source: NSE Website and audited Report (2016)

Table 3.1 shows targeted population of 4,409 workers from manufacturing firms listed at NSE in Kenya where a sample was drawn. Mumias Sugar Co. Ltd had highest number of 1,795 workers, followed by East Africa Breweries Ltd with 827 workers, then British American Tobacco with 500 workers, followed by Unga Group Ltd which had 425 workers, then B.O.C Kenya Ltd with 226 workers, followed by Eveready East Africa Ltd with 205 workers, then Flame Tree Group Holdings with 160 workers followed by Kenya Orchards Ltd with 102 workers then A. Baumann CO Ltd with 100 workers and finally Carbacid Investments Ltd with 69 workers.

\subsection{Sampling Design and Sample Size}

Cooper and Schindler (2007), state that the size of a sample should be a function of the variation in the population parameters under study and the estimating precision needed by the researcher. Sampling is the process of selecting a number of individuals for a study in such a way that the individuals selected represent the large group from which they were selected (Mugenda \& Mugenda 2012). Due to the nature of the study, the study considered the employees in specific departments and the actual target was Finance Officers, Human Resource Officers, Production Officers and Marketing Management Officers in each of the 10 companies. Since the population was small, census was conducted to obtain information from the population. According to Cooper \& Schindler (2007) when the population is small and variable, any sample we drew might not be representative of the population from which it is drawn; hence the whole population was considered for the study. Based on the staff population of 4,409 workers, a sample size of 102 officers was determined by using Naissium's formula (2000)

\subsubsection{Sample Size Calculation}

The study adopted Naissiuma's formula (2000) to calculate the size of the sample. The calculation of the sample size is outlined as follows.

Where

$$
n=\frac{N C^{2}}{C^{2}-(N-1) e^{2}}
$$

$n$ = Sample size;

$\mathrm{N}=$ population size;

$\mathrm{C}=$ Coefficient of variation which is $50 \%$;

$\mathrm{e}=$ margin of error which is fixed between $5 \%$.

$$
n=\frac{4409(0.5)^{2}}{(0.5)^{2}-(4409-1)(0.05)^{2}}
$$$$
n=102.3
$$$$
n=102 \text { respondents }
$$

From a population of 4,409 workers in ten manufacturing firms listed at NSE in Kenya, a sample size of 102 respondents was selected as shown in Table 3.2.

\begin{tabular}{|c|c|c|c|}
\hline $\begin{array}{l}\text { NSE Listed } \\
\text { Manufacturing } \\
\text { Firms }\end{array}$ & $\begin{array}{c}\text { Popu } \\
\text { lation } \\
\text { (No. } \\
\text { of } \\
\text { Work } \\
\text { ers) }\end{array}$ & $\begin{array}{l}\text { Populati } \\
\text { on/4409 }\end{array}$ & $\begin{array}{l}\text { Sample } \\
\text { Size } \\
\text { (Population } \\
/ 4409) * 102\end{array}$ \\
\hline B.O.C Kenya Ltd & 226 & 0.0513 & 5 \\
\hline $\begin{array}{l}\text { British American } \\
\text { Tobacco Kenya Ltd }\end{array}$ & 500 & 0.1134 & 12 \\
\hline $\begin{array}{c}\text { Carbacid } \\
\text { Investments Ltd }\end{array}$ & 69 & 0.0156 & 2 \\
\hline $\begin{array}{c}\text { East African } \\
\text { Breweries Ltd }\end{array}$ & 827 & 0.1876 & 19 \\
\hline $\begin{array}{l}\text { Mumias Sugar Co. } \\
\text { Ltd }\end{array}$ & 1,795 & 0.4071 & 41 \\
\hline Unga Group Ltd & 425 & 0.0964 & 10 \\
\hline $\begin{array}{c}\text { Eveready East } \\
\text { Africa Ltd }\end{array}$ & 205 & 0.0465 & 5 \\
\hline $\begin{array}{c}\text { Kenya Orchards } \\
\text { Ltd }\end{array}$ & 102 & 0.0231 & 2 \\
\hline $\begin{array}{l}\text { A. Baumann } \mathrm{CO} \\
\text { Ltd }\end{array}$ & 100 & 0.0227 & 2 \\
\hline $\begin{array}{c}\text { Flame Tree Group } \\
\text { Holdings }\end{array}$ & 160 & 0.0363 & 4 \\
\hline Total & 4,409 & 1.0000 & 102 \\
\hline
\end{tabular}

Table 3.2: Sample Size

Source: Author (2016) 
Table 3.2 shows the number of respondents drawn from each and every firm for the purpose of data collection. Mumias Sugar Co. Ltd had the highest respondents of 41 followed by East Africa Breweries Ltd with 19 respondents and lowest number of respondents was drawn from Carbacid Investments Ltd, Kenya Orchards Ltd and A. Baumann CO Ltd with 2 respondents.

The sample size for the research was 102 respondents (workers) who were distributed proportionately according to the survey organization depending on the size of the population. Stratified random sampling was used to obtain the respondents according to firms' departments namely; finance, human resource, marketing and production in ten listed manufacturing firms at NSE in Kenya. Four departments namely; finance, human resource, marketing and production were chosen to carry out research and act as a representative of the population.

\subsection{Data Collection Instruments}

Primary and secondary data were used in this study. The data was collected using questionnaires which had both open ended and closed questions. Saunders, Lewis and Thornhill (2009), define a questionnaire as a general term including all data collection techniques in which each person is asked to answer the same set of questions in a predetermined order.

\subsection{Data Collection Procedure}

Authority to collect data from ten manufacturing firms listed in the SEM in Kenya was sought from Kenyatta University and National Commission for Science, Technology and Innovation which acted as permission to access the firms of interest during the period of study. Three research assistants were identified to help drop and collect the questionnaires to various targeted officers under guidance of management. Meetings were held with targeted staff in the different listed manufacturing firms where the motive and the need for research was highlighted. The questionnaires were issued to the targeted staff and taken through the questions to be responded, Subsequently, follow-ups through phone calls and phone messages were carried out for appropriate data to be collected from respondents. The completed questionnaires were collected from the respondents ready for farther processing.

\subsection{Validity and Reliability of Research Instruments}

\subsubsection{Validity of Research Instruments}

Validity discusses the gradation to which a research study measures and processes what it intends to measure. According to Creswell (2012) validity is the progress of sound confirmation and proof to prove that the test interpretation of scores about the concept or construct that the test is assumed to measure matches its proposed use. Questionnaires in this study were given to five experts who looked at them independently to ascertain whether they contained information they purported to collect. Their views on the content and the structure of the questionnaires were incorporated in the final draft of the questionnaire.

\subsubsection{Reliability of Research Instruments}

To test reliability of questionnaires in this study, pilot test was administered to officers in finance, marketing, human resource and production in three local manufacturing companies. Test and re-test technique was also applied by administering same questionnaire to the same respondents and noting the scores from testing. Responses from the pilot study were thus exposed to a reliability test using Cronbach's alpha coefficient and results presented in Table 3.3.

Table 3.3 Reliability Test of Variables

\begin{tabular}{|c|c|c|c|}
\hline \multirow[b]{2}{*}{ Variables } & \multicolumn{3}{|c|}{ Reliability Tests } \\
\hline & $\begin{array}{l}\text { No. } \\
\text { of } \\
\text { Item } \\
\text { s }\end{array}$ & $\mathbf{N}$ & $\begin{array}{l}\text { Cronb } \\
\text { ach's } \\
\text { Alpha }\end{array}$ \\
\hline $\begin{array}{c}\text { HumanResource } \\
\text { Management }\end{array}$ & & & \\
\hline Selection and Recruitment & 5 & 24 & .730 \\
\hline Training and Development & 5 & 24 & .731 \\
\hline Succession and Career Path & 5 & 24 & .766 \\
\hline Marketing Management & & & \\
\hline Marketing Planning & 5 & 24 & .720 \\
\hline $\begin{array}{l}\text { Marketing Analysis and } \\
\text { Evaluation }\end{array}$ & 5 & 24 & .742 \\
\hline Marketing Control & 5 & 24 & .746 \\
\hline $\begin{array}{c}\text { Environmental } \\
\text { Management }\end{array}$ & & & \\
\hline $\begin{array}{l}\text { Laws and Regulation } \\
\text { Compliance }\end{array}$ & 5 & 24 & .724 \\
\hline Recycling of Wastes & 5 & 24 & .850 \\
\hline Environmental Planning & 5 & 24 & .762 \\
\hline
\end{tabular}

Source: Author (2016) 
In table 3.3 results, the Cronbach's alpha ranges from 0.720 to 0.850 for variables of human resource, marketing and environmental management hence consistent and is within the acceptable Cronbach's alpha of more than 0.7

\subsubsection{Piloting of the Study}

The pilot study is smaller version of a larger study that is conducted to prepare for that study. The term pilot study is used in two different ways in social science research. It can refer to so-called feasibility studies which are small scale version or trial run, done in preparation for the major study (Polit, Beck and Hungler, 2001). In this study, pilot study was done through questionnaires hand delivered to officers in finance, marketing, human resource and production in three local manufacturing companies where they filled and collected later for test of accuracy, validity and reliability.

\subsection{Data Analysis and Presentation}

Information was sorted, coded and input into the statistical package for social sciences (SPSS) version 22.0 for production of graphs, tables, descriptive statistics and inferential statistics. Data for this study were both qualitative and quantitative. Qualitative Data was analysed using descriptive statistics and presented using mean and frequency distribution. Inferential statistics including Chi-square tests were used to analyse quantitative data. According to Cooper and Schindler, (2011) application of inferential statistics enable the researcher estimate population on parameters and, test the hypotheses for the purpose of generalization of the findings. Chisquare was used to test the interdependence of the variables with below the formula.

$$
\chi_{c}^{2}=\sum \frac{\left(\mathbf{O}_{i}-E_{i}\right)^{2}}{E_{i}}
$$

\subsection{Ethical Considerations}

In this study the authors of the materials used to obtain information were recognised through referencing within the texts and reference. The consent of the respondents was also seeked through issuing the manufacturing institutions with introduction letter from Kenyatta University, permit letter from National Commission for Science, Technology and Innovation. Questionnaires were delivered to respondents individually and collected by the same staff to promote confidentiality of the information from the respondents.

\section{RESEARCH FINDINGS AND DISCUSSIONS 4.1 Introduction}

The chapter contains results of response rate, descriptive findings and inferential statistics. This chapter outline the analysis and presentation of data on the effects of human resource, marketing and environmental management on financial performance of manufacturing companies listed at Nairobi Securities Exchange market in Kenya.

\subsection{Response Rate}

The numbers of questionnaires administered to the respondents for collection of data were 102. The result is provided by figure 4.1

\section{Response Rate}

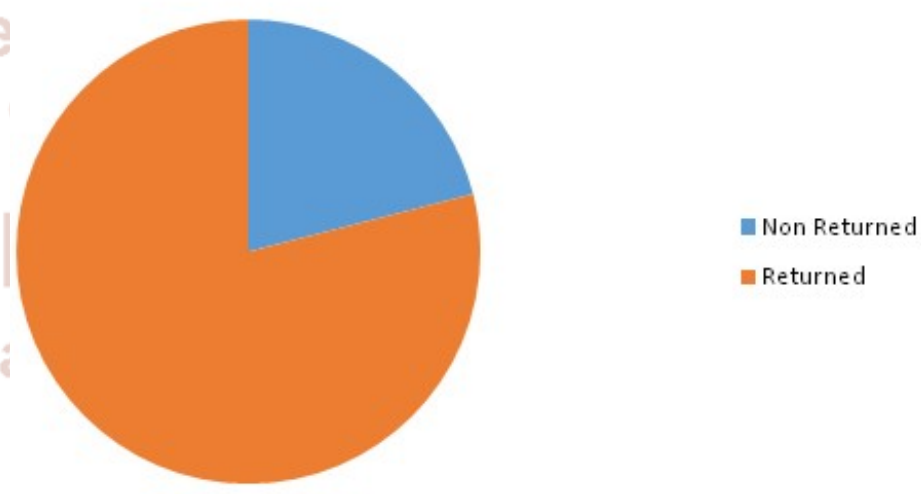

Figure 4.1: Response Rate

\section{Source: Author (2016)}

As indicated by figure 4.1, 77 questionnaires were completed by the respondents and returned. This number represented $76 \%$ response rate by the respondents who were issued with questionnaires for the purpose of collecting information. The response rate was satisfactory to make conclusions for the study. This is in accordance to Mugenda and Mugenda (2003) who states that a 50\% response rate is adequate, $60 \%$ good and above $70 \%$ rated very good. This was also supported by Gall, Borg, \& Gall, (2006) assertion that a response rate of $50 \%$ is adequate, while a response rate greater than $70 \%$ is very good. From the findings this implied that the response rate in this case of $80 \%$ was very good. The findings from the response rate of $76 \%$ was adequate to help us in making conclusion and recommendation on to determine effects of human resource, marketing and environmental management on financial performance of manufacturing companies listed at NSE in Kenya. 


\subsection{Human Resource Management and Financial Performance}

Human resource management is a significant component in a business operation. Efficient Human resource management influences financial performance. The first objective of the study was to determine the effect of human resource management on financial performance of manufacturing companies listed at Nairobi Securities Exchange in Kenya. It was hypothesized that human resource management has a significant effect on financial performance. The study sought to determine the effect of human resource management on financial performance of manufacturing companies listed at the NSE. The effect of human resource management on financial performance was analysed on the basis of selection and recruitment, training and development and succession and career path.

The results are presented using chi-square tests. The chi-square test was used to verify the possible relationship between two categorical variables. In this test a two-way table is created and the observed counts are compared to the expected counts of the cells. According to Moore and McCabe (2003) the chi-square statistic is a measure of how much the observed cell counts in a two-way table diverge from the expected cell counts.

\subsubsection{Selection and Recruitment and Financial Performance}

Selection and recruitment of staff, in particular, staff in finance operations was believed to have effect on financial performance of organizations. Finance is one of the key functions of the organization. This study aimed to find out the effects of staff selection and recruitment on financial performance of manufacturing firms listed at the NSE in Kenya. It was hypothesized that selection and recruitment of staff had no effect on financial performance of manufacturing firms listed at the NSE in Kenya. The respondents were asked to indicate on a scale of 1-5 their level of agreement with effect of selection and recruitment on financial performance. The results are presented by table 4.1

Table 4.1 Selection and Recruitment and Financial Performance Cross tabulation

\begin{tabular}{|c|c|c|c|c|c|c|}
\hline & \multicolumn{4}{|c|}{ Selection and Recruitment } & \multirow[t]{2}{*}{ Total } \\
\hline & & Increase accuracy & Increase efficiency & 4.00 & 5.00 & \\
\hline \multirow[t]{5}{*}{ Financial Performance } & Not at all & cocall 0 & 0 & 1 & 0 & 1 \\
\hline & Small Extent & eveloment & $1 \circlearrowleft$ & 7 & 0 & 8 \\
\hline & Moderate Extent & 1 & 1 & 13 & 14 & 29 \\
\hline & Large Extent & SNhe & 1 & 2 & 0 & 3 \\
\hline & Very Large Extent & 0 & 0 & 8 & 28 & 36 \\
\hline Tot & $11 \times 2+0$ & 1 & $\begin{array}{r}3 \\
\end{array}$ & 31 & 42 & 77 \\
\hline
\end{tabular}

\section{Source: Author (2016)}

The result in table 4.1 indicated that out of 77 respondents $(n=36)$ representing $47 \%$ showed that selection and recruitment affect financial performance of manufacturing firms to very large extent, while $(n=29)$ representing 38\% were the respondents who stated that selection and recruitment affects financial performance of manufacturing firms to moderate extent, while $(\mathrm{n}=8)$ representing $10 \%$ showed that that selection and recruitment affects financial performance of manufacturing firms to small extent, the $(n=3)$ representing $4 \%$ showed that selection and recruitment affects financial performance of manufacturing firms to small extent and finally $(\mathrm{n}=1)$ representing $1 \%$ showed that selection and recruitment does affect financial performance of manufacturing firms. The study established that majority of the respondent agreed that selection and recruitment affected financial performance.
To test the relationship between selection and recruitment on financial performance of manufacturing firms, a chi-test was carried out. The result is presented by Table 4.2

Table 4.2 Selection and Recruitment and Financial Performance Chi-Square Test

\begin{tabular}{|c|c|c|c|}
\hline & Value & Df & $\begin{array}{c}\text { Asymp. Sig. } \\
\text { (2-sided) }\end{array}$ \\
\hline $\begin{array}{c}\text { Pearson Chi- } \\
\text { Square }\end{array}$ & $45.854^{\mathrm{a}}$ & 12 & .000 \\
\hline Likelihood Ratio & 52.645 & 12 & .000 \\
\hline $\begin{array}{c}\text { Linear-by-Linear } \\
\text { Association }\end{array}$ & 24.834 & 1 & .000 \\
\hline N of Valid Cases & 77 & & \\
\hline
\end{tabular}

a. 16 cells $(80.0 \%)$ have expected count less than 5 .

The minimum expected count is .01 . 
The result of Chi- test showed $\chi^{2}=45.854$ with a Pvalue of 0.000 . The results indicated a significant positive relationship between selection and recruitment on financial performance of manufacturing firms listed at the NSE.

The result in table 4.2 was in agreement with the study of Batt (2002) which was on Managing customer services: Human resource practices, quit rates, and sales growth human resource practices particularly selection and recruitment have statistical positive influence on the financial performance of manufacturing firms. It also agreed with Preuss (2003) who studied Effects of human resource systems on manufacturing performance and turnover and concluded that HR practices like selection and recruitment influenced financial performance of manufacturing firms listed at NSE in Kenya. The result contradicted the study of Githinji (2014) which was on the effect of staff turnover on financial performance of private security firms in Kenya and concluded that staff turnover negatively affected the financial performance of private security firms in
Kenya through its impact on recruitment costs and lost productivity.

\subsubsection{Training and Development and Financial Performance}

Training and development of staff, in particular, staff in finance operations was believed to have effect on financial performance of organisations. Training and development of staff is concerned with organizational activity aiming at improving the skills and knowledge of staffs in organization in order to increase their efficiency and effectiveness hence improving financial performance of manufacturing firms. Finance is one of the key functions of the manufacturing firms. This study aimed to find out the effects of staff training and development on financial performance of manufacturing firms listed at the NSE in Kenya. It was hypothesised that training and development of staff had no effect on financial performance of manufacturing firms listed at the NSE in Kenya. The respondents were asked to indicate on a scale of 1-5 their level of agreement with effect of training and development on financial performance. The results are presented by table 4.3

Table 4.3: Training \& Development and Financial Performance Cross tabulation

\begin{tabular}{|c|c|c|c|c|c|c|}
\hline & \multicolumn{4}{|c|}{ Training \& Development } & \multirow[t]{2}{*}{ Total } \\
\hline & & Increase Accuracy & Increase Efficiency & 4.00 & 5.00 & \\
\hline \multirow{5}{*}{ Financial Performance } & Not at all & Develc 0 ment & 0 & 0 & 0 & 0 \\
\hline & Small Extent & 0 & 1 & 2 & 0 & 3 \\
\hline & Moderate Extent & col 1 & 1 & 4 & 4 & 10 \\
\hline & Large Extent & $010.2410=0410$ & 1 & 25 & 0 & 27 \\
\hline & Very Large Extent & 0 & 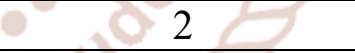 & 1 & 34 & 37 \\
\hline \multicolumn{2}{|c|}{ Total } & 2 & 5 & 32 & 38 & 77 \\
\hline
\end{tabular}

\section{Source: Author (2016)}

The results in table 4.3 indicated that out of 77 respondents $(n=37)$ representing $48 \%$ showed that training and development affects financial performance of manufacturing firms to a very large extent, while $(\mathrm{n}=10)$ representing $13 \%$ showed that training and development affects financial performance of manufacturing firms to moderate extent, while $(\mathrm{n}=27)$ representing $35 \%$ stated that that training and development affects financial performance of manufacturing firms to large extent, the $(n=3)$ representing $4 \%$ stated that training and development affects financial performance to small extent and finally $(\mathrm{n}=0)$ representing $0 \%$ stated that training and development does affects financial performance. The study established that majority of the respondent agreed that training \& development affected financial performance.
To test the relationship between training and development on financial performance of manufacturing firms, a chi-test was carried out. The result is presented by Table 4.4

Table 4.4: Training \& Development and Financial Performance Chi-Square Tests

\begin{tabular}{|c|c|c|c|}
\hline & Value & Df & $\begin{array}{c}\text { Asymp. Sig. } \\
\text { (2-sided) }\end{array}$ \\
\hline Pearson Chi-Square & $38.796^{\mathrm{a}}$ & 12 & .000 \\
\hline Likelihood Ratio & 47.587 & 12 & .000 \\
\hline $\begin{array}{c}\text { Linear-by-Linear } \\
\text { Association }\end{array}$ & 15.327 & 1 & .000 \\
\hline N of Valid Cases & 77 & & \\
\hline $\begin{array}{c}\text { a. 16 cells (80.0\%) have expected count less than 5. } \\
\text { The minimum expected count is .01. }\end{array}$ \\
\hline
\end{tabular}

Source: Author (2016) 
The result in table 4.4 of Chi- test showed $\chi^{2}=38.796$ with a P- value of 0.000 . The results indicated a significant positive relationship between training and development on financial performance of manufacturing firms listed at the NSE.

The result is in agreement with the study of Liao (2005) on business strategy and performance: the role of human resource management control which concluded that human resource function has a effect on financial performance. The result of this study is also in agreement with Wanyama and Mutsotso (2010) study on relationship between capacity building and employee productivity on performance of commercial banks in Kenya and concluded that training and development through capacity building and productivity have positive correlation on firm's financial performance.

\subsubsection{Succession and Career path and Financial Performance}

Succession and career path of staff, in particular, staff in finance operations was believed to have effect on financial performance of organizations. Succession and career path of staff result in the retention of high potential staff and builds internal staff capabilities to meet business needs and risk management as far as the future financial performance of the firm is concerned. Finance is one of the key functions of the organization which requires continuity hence needs preparation of staff for future takeover. This study aimed to find out the effects of succession and career path on financial performance of manufacturing firms listed at the NSE in Kenya. It was hypothesised that succession and career path of staff had no effect on financial performance of manufacturing firms listed at the NSE in Kenya. The respondents were asked to indicate on a scale of $1-5$ their level of agreement with effect of succession and career path on financial performance. The results are presented by table 4.5

Table 4.5: Succession and career path and Financial Performance Cross tabulation

\begin{tabular}{|c|c|c|c|c|c|c|}
\hline & \multicolumn{4}{|c|}{ Succession and career path } & \multirow[t]{2}{*}{ Total } \\
\hline & & $\begin{array}{l}\text { Not at } \\
\text { all }\end{array}$ & $\begin{array}{c}\text { Small } \\
\text { Extent }\end{array}$ & $\begin{array}{c}\text { Moderate } \\
\text { Extent }\end{array}$ & $\begin{array}{l}\text { Large } \\
\text { Extent }\end{array}$ & \\
\hline \multirow{5}{*}{$\begin{array}{l}\text { Financial } \\
\text { Performance }\end{array}$} & Not at all & 0 & 0 & 00 & 0 & 0 \\
\hline & Small Extent & 1 & 5 काति & 3 & 0 & 9 \\
\hline & Moderate Extent & 3 Devg & 9 oment & 00 & 0 & 26 \\
\hline & Large Extent & 0 & 1 & 20 & 0 & 3 \\
\hline & Very Large Extent & & $0=0.970$ & 19 & 20 & 39 \\
\hline Total & (1/2) & $4 \cup 1 \mathrm{~N}$ & $150-040$ & $38 \quad 0 \div$ & 20 & 77 \\
\hline
\end{tabular}

\section{Source: Author (2016)}

The result in table 4.5 indicated that out of 77 respondents $(\mathrm{n}=26)$ representing $34 \%$ indicated that succession and career path affects financial performance to very large extent, while $(n=39)$ representing $51 \%$ were the respondents who stated that succession and career path affects financial performance to moderate extent, while $(n=9)$ representing $12 \%$ stated that that succession and career path affects financial performance to small extent, the $(n=3)$ representing $4 \%$ stated that succession and career path affects financial performance to small extent and finally $(\mathrm{n}=0)$ representing $0 \%$ stated that succession and career path does affects financial performance. The study established that majority of the respondent agreed that selection and recruitment affects financial performance.
To test the relationship between succession and career path on financial performance of manufacturing firms, a chi-test was carried out. The result is presented by table 4.6.

Table 4.6: Succession and career path and Financial Performance Chi-Square Tests

\begin{tabular}{|c|c|c|c|}
\hline & Value & Df & $\begin{array}{c}\text { Asymp. Sig. (2- } \\
\text { sided) }\end{array}$ \\
\hline $\begin{array}{c}\text { Pearson Chi- } \\
\text { Square }\end{array}$ & $69.507^{\mathrm{a}}$ & 12 & .000 \\
\hline Likelihood Ratio & 71.101 & 12 & .000 \\
\hline $\begin{array}{c}\text { Linear-by-Linear } \\
\text { Association }\end{array}$ & 40.636 & 1 & .000 \\
\hline N of Valid Cases & 77 & & \\
\hline $\begin{array}{l}\text { a. } 14 \text { cells (70.0\%) have expected count less than 5. } \\
\text { The minimum expected count is .06. }\end{array}$ \\
\hline
\end{tabular}

Source: Author (2016) 
The result in table 4.6 of Chi- test showed $\chi^{2}=69.507$ with a P- value of 0.000 . The results indicated a significant positive relationship between succession and career path on financial performance of manufacturing firms listed at the NSE.

The result of this study is in agreement with the study of Vance (2009) on Corporate Restructuring: From Cause Analysis to Execution and concluded that degree of financial performance is dependent on proper supervision and leadership of the organization. The result of study is also in agreement with Kimosop (2007) study on Labour Turnover in Private Security Firms in Kenya and concluded that career prospects in the firm affects financial performance of the firm.

\subsection{Marketing Management and Financial Performance}

Marketing management is a significant component in a business operation since it is the concept that is responsible for identifying, anticipating and satisfying customer requirements profitably. Efficient marketing management influences financial performance. It was hypothesized that marketing management has a significance effect on financial performance. The study sought to determine the effect of marketing management on financial performance of manufacturing companies listed at the NSE. The second objective of the study was to determine the effect of marketing management on financial performance of manufacturing companies listed at Nairobi Securities Exchange in Kenya. The effect of marketing management on financial performance was analysed on the basis of Marketing Planning, Market Analysis and Evaluation and Marketing Control.
The results were presented using chi-square tests. The chi-square test was used to verify the possible relationship between two categorical variables. In this test a two-way table is created and the observed counts are compared to the expected counts of the cells. According to Moore and McCabe (2003) the chi-square statistic is a measure of how much the observed cell counts in a two-way table diverge from the expected cell counts.

\subsubsection{Marketing Planning and Financial Performance}

Marketing planning of products, in particular, goods and services in production operations was believed to have effect on financial performance of organizations. Therefore, the benefits of marketing planning would, arguably, be in direct relation to the achievement of the intended marketing objectives and the contribution to the realization of the company's growth potential. At the same time, it should be indicated that since marketing objectives are designed to facilitate the overall organizational performance hence improving financial performance of manufacturing firms. Finance is one of the key functions of the manufacturing firms. This study aimed to find out the effects of / marketing planning on financial performance of manufacturing firms listed at the NSE in Kenya. It was hypothesized that marketing planning of goods and services had no effect on financial performance of manufacturing firms listed at the NSE in Kenya. The respondents were asked to indicate on a scale of $1-5$ their level of agreement with effect of marketing planning on financial performance. The results are presented by table 4.7 .

Table 4.7: Marketing Planning and Financial Performance * Cross tabulation

\begin{tabular}{|c|c|c|c|c|c|c|}
\hline \multicolumn{7}{|c|}{ Count } \\
\hline & & \multicolumn{4}{|c|}{ Marketing Planning } & \multirow[t]{2}{*}{ Total } \\
\hline & & $\begin{array}{l}\text { Increase } \\
\text { Effectiveness }\end{array}$ & $\begin{array}{l}\text { Increase } \\
\text { Accuracy }\end{array}$ & $\begin{array}{l}\text { Increase } \\
\text { Efficiency }\end{array}$ & 5.00 & \\
\hline \multirow{5}{*}{$\begin{array}{c}\text { Financial } \\
\text { Performance }\end{array}$} & Not at all & 0 & 3 & 1 & 0 & 4 \\
\hline & Small Extent & 1 & 1 & 3 & 0 & 5 \\
\hline & Moderate Extent & 3 & 13 & 14 & 0 & 30 \\
\hline & Large Extent & 2 & 0 & 6 & 0 & 8 \\
\hline & Very Large Extent & 2 & 1 & 8 & 19 & 30 \\
\hline \multicolumn{2}{|c|}{ Total } & 8 & 18 & 32 & 19 & 77 \\
\hline
\end{tabular}

\section{Source: Author (2016)}

The results in table 4.7 indicated that out of 77 respondents $(\mathrm{n}=30)$ representing $39 \%$ indicated that marketing planning affects financial performance to very large extent, while $(\mathrm{n}=30)$ representing $39 \%$ were the respondents who stated that marketing planning affects financial performance to moderate extent, while $(n=5)$ representing $7 \%$ stated that that marketing planning affects financial performance to 
small extent, the $(n=8)$ representing $10 \%$ stated that marketing planning affects financial performance to small extent and finally $(\mathrm{n}=4)$ representing $5 \%$ stated that marketing planning does affects financial performance. The study established that majority of the respondent agreed that marketing planning affects financial performance.

To test the relationship between marketing planning on financial performance of manufacturing firms, a chi-test was carried out. The result is presented by table 4.8.

Table 4.8: Marketing Planning and Financial ChiSquare Tests

\begin{tabular}{|c|c|c|c|}
\hline & Value & Df & $\begin{array}{c}\text { Asymp. Sig. } \\
\text { (2-sided) }\end{array}$ \\
\hline $\begin{array}{c}\text { Pearson Chi- } \\
\text { Square }\end{array}$ & $53.950^{\mathrm{a}}$ & 12 & .000 \\
\hline Likelihood Ratio & 59.750 & 12 & .000 \\
\hline $\begin{array}{c}\text { Linear-by-Linear } \\
\text { Association }\end{array}$ & 24.871 & 1 & .000 \\
\hline N of Valid Cases & 77 & & \\
\hline
\end{tabular}

a. 12 cells $(60.0 \%)$ have expected count less than 5 . The minimum expected count is .18 .

\section{Source: Author (2016)}

The result in table 4.8 of Chi- test showed $\chi^{2}=53.950$ with a P- value of 0.000 . The results indicated a significant positive relationship between marketing planning on financial performance of manufacturing firms listed at the NSE
The result is in agreement with the study by $\mathrm{Li}$ (2000) on Default Correlation between Marketing and Financial Performance and concluded that emphasizing responsiveness, meeting the customer's needs through providing pre-sale, transactional, and post-sale services can improve sales volume and positively affect financial performance. It is also in agreement with study of Kombo (2015) on Customer satisfaction in the Kenyan banking industry and concluded that customer satisfaction which requires marketing planning would, arguably, be in direct relation to overall organisational performance.

\subsubsection{Market Analysis and Evaluation and Financial Performance}

Market analysis and evaluation of customers, regions price and products as components of marketing strategy was believed to have effect on financial performance of organizations. Market analysis and evaluation helps in improving financial performance of manufacturing firms. Finance is one of the key functions of the manufacturing firms. This study aimed to find out the effects of market analysis and evaluation on financial performance of manufacturing firms listed at the NSE in Kenya. It was hypothesized that market analysis and evaluation had no effect on financial performance of manufacturing firms listed at the NSE in Kenya. The respondents were asked to indicate on a scale of 1-5 their level of agreement with effect of market analysis on financial performance. The results are presented by table 4.9.

Table 4.9: Market Analysis and Evaluation and Financial Performance * Cross tabulation

\begin{tabular}{|c|c|c|c|c|c|c|}
\hline \multicolumn{2}{|c|}{} & \multicolumn{2}{|c|}{ Market Analysis and Evaluation } & Total \\
\cline { 2 - 7 } & Increase Accuracy & Increase Efficiency & $\mathbf{4 . 0 0}$ & $\mathbf{5 . 0 0}$ & \\
\hline \multirow{3}{*}{ Financial Performance } & Not at all & 1 & 0 & 0 & 0 & 1 \\
\cline { 2 - 7 } & Small Extent & 1 & 7 & 0 & 0 & 8 \\
\cline { 2 - 7 } & Moderate Extent & 10 & 26 & 0 & 0 & 36 \\
\cline { 2 - 7 } & Large Extent & 0 & 3 & 0 & 0 & 3 \\
\cline { 2 - 7 } & Very Large Extent & 9 & 1 & 14 & 5 & 29 \\
\hline
\end{tabular}

Source: Author (2016)

The results in table 4.9 indicated that out of 77 respondents $(n=36)$ representing $47 \%$ indicated that market analysis and evaluation affects financial performance to very large extent, while $(n=29)$ representing 38\% were the respondents who stated that market analysis and evaluation affects financial performance to moderate extent, while $(n=8)$ representing $10 \%$ stated that market analysis and evaluation affects financial performance to small extent, the $(n=3)$ representing $4 \%$ stated that market analysis and evaluation affects financial performance to small extent, the $(\mathrm{n}=1)$ representing $1 \%$ stated that market analysis and evaluation does affect financial performance and finally $(\mathrm{n}=1)$ representing $1 \%$ stated that market analysis and evaluation does affects financial performance. The study established that 
majority of the respondent agreed market analysis and evaluation affects financial performance.

To test the relationship between market analysis and evaluation on financial performance of manufacturing firms, a chi-test was carried out. The result is presented by table 4.10 .

Table 4.10: Market Analysis and Evaluation and Financial Performance Chi-Square Tests

\begin{tabular}{|c|c|c|c|}
\hline $\begin{array}{c}\text { Pearson Chi- } \\
\text { Square }\end{array}$ & $56.140^{\mathrm{a}}$ & 12 & $\begin{array}{c}\text { Asymp. Sig. } \\
\text { (2-sided) }\end{array}$ \\
\hline Likelihood Ratio & 69.546 & 12 & .000 \\
\hline $\begin{array}{c}\text { Linear-by-Linear } \\
\text { Association }\end{array}$ & 13.699 & 1 & .000 \\
\hline N of Valid Cases & 77 & & \\
\hline
\end{tabular}

a. 14 cells $(70.0 \%)$ have expected count less than 5 .

The minimum expected count is .06.

\section{Source: Author (2016)}

The result in table 4.10 of Chi- test showed $\chi^{2}$ $=56.140$ with a P- value of 0.000 . The results indicated a significant positive relationship between market analysis and evaluation and financial performance of manufacturing firms listed at the NSE The result is in agreement with the study by Ghosh, Dutta and Stremersch (2006) on customizing complex products: When should the vendor take control? Where they concluded that competitive advantages stemming from marketing practices designed to increase customer satisfaction, or in other words, the customer centric approach is thought to increase financial performance and profitability. It also concurred with study of Raju and Lonial's (2002) on the impact of service quality and marketing on financial performance in the hospital industry: an empirical examination studies which concluded that new product/service development, research and development of new innovations, building competitive advantage, and creating new markets are significantly positively related to financial performance.

\subsubsection{Marketing Control and Financial Performance}

Marketing control of products, in particular, goods and services in product promotion operations was believed to have effect on financial performance of organizations. Marketing control helps in determining areas of marketing mix to modify and as well as whether manufacturing firm's goods, services and ideas meet customer and stakeholders needs to contribute to organizational performance hence improving financial performance of manufacturing firms. Finance is one of the key functions of the manufacturing firms. This study aimed to find out the effects of marketing control on financial performance of manufacturing firms listed at the NSE in Kenya. It was hypothesized that marketing control of goods and services has no effect on financial performance of manufacturing firms listed at the NSE in Kenya. The respondents were asked to indicate on a scale of 1-5 their level of agreement with effect of marketing control on financial performance. The results are presented by Table 4.11 .

Table 4.11: Marketing Control Financial Performance Cross tabulation

\begin{tabular}{|c|c|c|c|c|c|c|}
\hline & \multicolumn{4}{|c|}{ Marketing Control } & \multirow[t]{2}{*}{ Total } \\
\hline & & $\begin{array}{c}\text { Increase } \\
\text { Effectiveness }\end{array}$ & $\begin{array}{l}\text { Increase } \\
\text { Accuracy }\end{array}$ & $\begin{array}{l}\text { Increase } \\
\text { Efficiency }\end{array}$ & 5.00 & \\
\hline \multirow{5}{*}{$\begin{array}{c}\text { Financial } \\
\text { Performance }\end{array}$} & Not at all & 0 & 0 & 0 & 0 & 0 \\
\hline & Small Extent & 0 & 0 & 0 & 0 & 0 \\
\hline & Moderate Extent & 17 & 13 & 0 & 0 & 30 \\
\hline & Large Extent & 10 & 2 & 0 & 0 & 12 \\
\hline & Very Large Extent & 5 & 5 & 7 & 18 & 35 \\
\hline \multicolumn{2}{|c|}{ Total } & 32 & 20 & 7 & 18 & 77 \\
\hline
\end{tabular}

\section{Source: Author (2016)}

The result in table 11 indicated that out of 77 respondents $(n=35)$ representing $45 \%$ indicated that marketing control affects financial performance to very large extent, while $(n=30)$ representing 39\% were the respondents who stated that marketing control affects financial performance to moderate extent, while $(\mathrm{n}=0)$ representing $0 \%$ stated that that marketing control affects financial performance to small extent, the $(\mathrm{n}=12)$ representing $16 \%$ stated that marketing control affects financial performance to 
small extent and finally $(\mathrm{n}=0)$ representing $0 \%$ stated that marketing control does affects financial performance. The study established that majority of the respondent agreed that marketing control affects financial performance.

To test the relationship between marketing controls on financial performance of manufacturing firms, a chitest was carried out. The result is presented by Table 4.12.

Table 4.12: Marketing Control Financial Performance Chi-Square Tests

\begin{tabular}{|c|c|c|c|}
\hline & Value & Df & $\begin{array}{l}\text { Asymp. Sig. } \\
\text { (2-sided) }\end{array}$ \\
\hline $\begin{array}{c}\text { Pearson Chi- } \\
\text { Square }\end{array}$ & $38.842^{\mathrm{a}}$ & 12 & .000 \\
\hline Likelihood Ratio & 46.194 & 12 & .000 \\
\hline $\begin{array}{c}\text { Linear-by-Linear } \\
\text { Association }\end{array}$ & 20.027 & 1 & .000 \\
\hline N of Valid Cases & 77 & & \\
\hline
\end{tabular}

a. 14 cells $(70.0 \%)$ have expected count less than 5 . The minimum expected count is .01 .

\section{Source: Author (2016)}

The result in table 12 of Chi- test showed $\chi^{2}=38.842$ with a P- value of 0.000 . The result indicated a significant positive relationship between marketing controls on financial performance of manufacturing firms listed at the NSE

The result is in agreement with the study by Owino (2013) on the Influence of control of service quality and corporate image on customer satisfaction among university students in Kenya, which concluded that control service quality, corporate image and customer satisfaction had a significant positive influence on financial performance of Kenyan public universities. The result is also in agreement with the study of Lee and Roh (2012) on Revisiting corporate reputation and firm performance link which concluded that market practices control on key factors like reputation and image directly influence financial performance of organization.

\subsection{Environmental Management and Financial Performance}

Environment management is a significant component in a business operation. Efficient environment management influences financial performance. It was hypothesized that environmental management had a significant effect on financial performance. The study sought to determine the effect of environment management on financial performance of manufacturing companies listed at the NSE. The third objective of the study was to determine the effect of environment management on financial performance of manufacturing companies listed at Nairobi Securities Exchange market in Kenya. The effect of environmental management on financial performance was analysed on the basis of Laws and regulations Compliance and Recycling of wastes and Environmental Planning.

The results are presented using chi-square tests. The chi-square test is used to verify the possible relationship between two categorical variables. In this test a two-way table is created and the observed counts are compared to the expected counts of the cells. According to Moore and McCabe (2003) the chi-square statistic is a measure of how much the observed cell counts in a two-way table diverge from the expected cell counts.

\subsubsection{Laws and regulations Compliance and Financial Performance}

Laws and regulations of government and government agencies were established to guide the conduct and operations of the businesses and were believed to have effect on financial performance of organizations. Laws and regulations make manufacturing firms to embrace more eco friendly activities such as the integration of design for the environment into their products and the use of sustainable distribution practices. Finance is one of the key functions of the manufacturing firms. This study aimed to find out the effects of laws and regulation compliance on financial performance of manufacturing firms listed at the NSE in Kenya. It was hypothesized that laws and regulation compliance have no effect on financial performance of manufacturing firms listed at the NSE in Kenya. The respondents were asked to indicate on a scale of 1-5 their level of agreement with effect of laws and regulations compliance on financial performance. The results are presented by table 4.13. 
International Journal of Trend in Scientific Research and Development (IJTSRD) ISSN: 2456-6470

Table 4.13: Laws and regulations Compliance Financial Performance Cross tabulation

\begin{tabular}{|c|c|c|c|c|c|}
\hline & \multicolumn{3}{|c|}{ Laws and regulations Compliance } & \multirow[t]{2}{*}{ Total } \\
\hline & & $\begin{array}{c}\text { Increase } \\
\text { Effectiveness }\end{array}$ & $\begin{array}{l}\text { Increase } \\
\text { Accuracy }\end{array}$ & $\begin{array}{l}\text { Increase } \\
\text { Efficiency }\end{array}$ & \\
\hline \multirow{5}{*}{$\begin{array}{l}\text { Financial } \\
\text { Performance }\end{array}$} & Not at all & 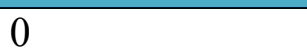 & 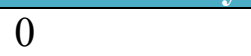 & - & 4 \\
\hline & Small Extent & 1 & 4 & 6 & 11 \\
\hline & Moderate Extent & 9 & 7 & 14 & 30 \\
\hline & Large Extent & 0 & 0 & 0 & 0 \\
\hline & Very Large Extent & 2 & 19 & 11 & 32 \\
\hline \multicolumn{2}{|l|}{ Total } & 12 & 30 & 35 & 77 \\
\hline
\end{tabular}

Source: Author (2016)

The result in table 4.13 indicated that out of 77 The result is in agreement with the study by Dowel, respondents $(\mathrm{n}=32)$ representing $42 \%$ indicated that laws and regulations compliance affects financial performance to very large extent, while $(n=30)$ representing $39 \%$ were the respondents who stated that laws and regulations compliance affects financial performance to moderate extent, while $(n=11)$ representing 14\% stated that that laws and regulations compliance affects financial performance to small extent, the $(n=3)$ representing $4 \%$ stated that laws and regulations compliance affects financial performance to small extent and finally $(\mathrm{n}=0)$ representing $0 \%$ stated that laws and regulations compliance does affects financial performance. The study established that majority of the respondent agreed that laws and regulations compliance affects financial performance.

To test the relationship between laws and regulations compliance on financial performance of manufacturing firms, a chi-test was carried out. The result is presented by Table 4.14 .

Hart and Yeung (2000) on Do corporate global environmental standards create or destroy market value? The conclusion was that firms that adopt single stringent environmental standards worldwide have higher market valuations than firms that do not adopt such standards. It also agrees with Kierman (1998) study on the eco-efficiency revolution on organization performance which concluded that environmental compliance as future capital market return has positive effect on organisation performance. The result of the study contradicts the study by Naila (2013) on The Effect of Environmental Regulations on Financial Performance in Tanzania: A Survey of Manufacturing Companies Quoted on the Dar Es Salaam Stock Exchange which concluded that environmental compliance had no significant effect on the financial performance of the listed manufacturing firms.

\subsubsection{Recycling of wastes and Financial Performance}

Table 4.14: Laws and regulations Compliance and Financial Performance Chi-Square Tests

\begin{tabular}{|c|c|c|c|}
\hline & Value & df & $\begin{array}{c}\text { Asymp. Sig. (2- } \\
\text { sided) }\end{array}$ \\
\hline Pearson Chi-Square & $19.056^{\mathrm{a}}$ & 8 & .015 \\
\hline Likelihood Ratio & 19.370 & 8 & .013 \\
\hline $\begin{array}{c}\text { Linear-by-Linear } \\
\text { Association }\end{array}$ & .837 & 1 & .360 \\
\hline N of Valid Cases & 77 & & \\
\hline $\begin{array}{l}\text { a. } 9 \text { cells (60.0\%) have expected count less than 5. } \\
\text { The minimum expected count is .18. }\end{array}$ \\
\hline
\end{tabular}

\section{Source: Author (2016)}

The result in table 4.14 of Chi- test showed $\chi^{2}$ $=19.056$ with a P- value of 0.015 . The results indicated a significant positive relationship between laws and regulation compliance and financial performance of manufacturing firms listed at the NSE.

Recycling of waste products, in particular, waste products in production operations was believed to have effect on financial performance of organizations. Recycling of wastes from the firms' operations is environmental management technique which is geared towards not only improving environment through which the firm can increase its own profit and strengthen its long-term competitiveness, as well as making a meaningful environmental impact hence financial performance adjustment of the firm. Finance was one of the key functions of the manufacturing firms. This study aimed to find out the effects of recycling of wastes on financial performance of manufacturing firms listed at the NSE in Kenya. It was hypothesized that recycling of wastes had no effect on financial performance of manufacturing firms listed at the NSE in Kenya. The respondents were asked to indicate on a scale of 1-5 their level of agreement with effect of recycling of wastes on 
financial performance. The results are presented by Table 4.15.

Table 4.15: Recycling of wastes and Financial Performance * Cross tabulation

\begin{tabular}{|c|c|c|c|c|c|}
\hline \multirow{2}{*}{\multicolumn{2}{|c|}{}} & \multicolumn{3}{|c|}{ Recycling of wastes } & Total \\
\cline { 3 - 6 } & $\begin{array}{c}\text { Increase } \\
\text { Effectiveness }\end{array}$ & $\begin{array}{c}\text { Increase } \\
\text { Accuracy }\end{array}$ & $\begin{array}{c}\text { Increase } \\
\text { Efficiency }\end{array}$ \\
\hline \multirow{3}{*}{$\begin{array}{c}\text { Financial } \\
\text { Performance }\end{array}$} & Not at all & 0 & 1 & 0 & 1 \\
\cline { 2 - 6 } & Small Extent & 0 & 1 & 0 & 1 \\
\cline { 2 - 6 } & Moderate Extent & 0 & 0 & 6 & 6 \\
\cline { 2 - 6 } & Large Extent & 0 & 5 & 22 & 27 \\
\cline { 2 - 6 } & Very Large Extent & 2 & 33 & 42 & 77 \\
\hline
\end{tabular}

\section{Source: Author (2016)}

The results in table 4.15 indicated that out of 77 respondents $(n=42)$ representing $55 \%$ indicated that recycling of wastes affects financial performance to very large extent, while $(n=6)$ representing $8 \%$ were the respondents who stated that recycling of wastes affects financial performance to moderate extent, while $(n=1)$ representing $1 \%$ stated that that recycling of wastes affects financial performance to small extent, the $(n=27)$ representing $35 \%$ stated that recycling of wastes affects financial performance to large extent and finally $(n=1)$ representing $1 \%$ stated that recycling of wastes does affects financial performance. The study established that majority of the respondent agreed that recycling of wastes affects financial performance.

To test the relationship between recycling of wastes on financial performance, a chi-test was carried out. The result is presented by Table 4.16.

Table 4.16: Recycling of wastes and Financial Performance * Chi-Square Tests

\begin{tabular}{|c|c|c|c|}
\hline $\begin{array}{c}\text { Pearson Chi- } \\
\text { Square }\end{array}$ & $41.592^{\mathrm{a}}$ & 8 & .000 \\
\hline Likelihood Ratio & 50.830 & 8 & .000 \\
\hline $\begin{array}{c}\text { Linear-by-Linear } \\
\text { Association }\end{array}$ & 28.830 & 1 & .000 \\
\hline N of Valid Cases & 77 & & \\
\hline
\end{tabular}

a. 11 cells $(73.3 \%)$ have expected count less than 5 . The minimum expected count is .03 .

\section{Source: Author (2016)}

The result in table 4.16 of Chi- test showed $\chi^{2}$ $=41.592$ with a P- value of 0.000 . The results indicated a significant positive relationship between recycling of wastes and financial performance of manufacturing firms listed at the NSE

The result is in agreement by the study of Zhu, Sarkis and Lai (2006) on Green supply chain management: pressures, practices and performance within the Chinese automobile industry which concluded that managers addressing the environmental concern of the customer and mitigate the environmental impact of their products and services have positive financial performance. It also concurred with study of Maru, Chepwony and Menjo (2012) on Recycling of waste as a determinant of financial performance of Small and medium enterprises in Eldoret Town, Kenya which concluded that recycling as one of waste recycling strategies shows it affects financial performance of SMEs.

\subsubsection{Environmental Planning and Financial Performance}

Environmental planning as components of environmental management was believed to have effect on financial performance of organizations. Environmental planning was the process of facilitating decision making to carry out land development with the consideration given to the natural environment. The goal for environmental planning was to create sustainable community. Finance was one of the key functions of the manufacturing firms. This study aimed to find out the effects of environmental planning on financial performance of manufacturing firms listed at the NSE in Kenya. It was hypothesized that environmental planning has no effect on financial performance of manufacturing firms listed at the NSE in Kenya. The respondents were asked to indicate on a scale of 1-5 their level of agreement with effect of environmental planning on financial performance. The results are presented by table 4.17 . 
International Journal of Trend in Scientific Research and Development (IJTSRD) ISSN: 2456-6470

Table 4.17: Environmental Planning and Financial Performance * Cross tabulation

\begin{tabular}{|c|c|c|c|c|c|}
\hline & \multicolumn{3}{|c|}{ Environmental Planning } & \multirow[t]{2}{*}{ Tota } \\
\hline & & $\begin{array}{c}\text { Increase } \\
\text { Effectiveness }\end{array}$ & $\begin{array}{l}\text { Increase } \\
\text { Accuracy }\end{array}$ & $\begin{array}{l}\text { Increase } \\
\text { Efficiency }\end{array}$ & \\
\hline \multirow{5}{*}{$\begin{array}{c}\text { Financial } \\
\text { Performance }\end{array}$} & Not at all & 0 & 0 & 0 & 0 \\
\hline & Small Extent & 0 & 0 & 0 & 0 \\
\hline & Moderate Extent & 1 & 19 & 0 & 20 \\
\hline & Large Extent & 18 & 2 & 0 & 20 \\
\hline & Very Large Extent & 16 & 15 & 6 & 37 \\
\hline \multicolumn{2}{|c|}{ Total } & 35 & 36 & 6 & 77 \\
\hline
\end{tabular}

\section{Source: Author (2016)}

The result in table 4.17 indicated that out of 77 The result is in agreement with the study by Kierman respondents $(\mathrm{n}=37)$ representing $48 \%$ indicated that environmental planning affects financial performance to very large extent, while $(n=20)$ representing $26 \%$ were the respondents who stated that environmental planning affects financial performance to moderate extent, while $(n=20)$ representing $26 \%$ stated that that environmental planning affects financial performance to small extent, the $(n=0)$ representing $0 \%$ stated that environmental planning affects financial performance to small extent and finally $(\mathrm{n}=0)$ representing $0 \%$ stated that environmental planning does affects financial performance. The study//showed that majority of the respondent agreed that environmental planning affected financial performance.

To test the relationship between environmental planning on financial performance of manufacturing firms, a chi-test was carried out. The result is presented by Table 4.18 .

Table 4.18: Environmental Planning and Financial Performance * Chi-Square Tests

\begin{tabular}{|c|c|c|c|}
\hline & Value & Df & $\begin{array}{c}\text { Asymp. } \\
\text { Sig. } \\
\text { (2-sided) }\end{array}$ \\
\hline Pearson Chi-Square & $14.256^{\mathrm{a}}$ & 8 & .075 \\
\hline Likelihood Ratio & 16.391 & 8 & .037 \\
\hline $\begin{array}{c}\text { Linear-by-Linear } \\
\text { Association }\end{array}$ & 9.883 & 1 & .002 \\
\hline N of Valid Cases & 77 & & \\
\hline
\end{tabular}

a. 11 cells $(73.3 \%)$ have expected count less than 5 .

The minimum expected count is .08 .

\section{Source: Author (2016)}

The result in table 4.18 of Chi- test showed $\chi^{2}$ $=14.256$ with a P- value of 0.075 . The results indicated a significant positive relationship between environmental planning and financial performance of manufacturing firms listed at the NSE.

(1998) on the eco-efficiency revolution on organization performance which concluded that environmental performance has effect on financial performance. It also agreed with study of Zhu, Sarkis and Lai (2006) on Green supply chain management: pressures, practices and performance within the Chinese automobile industry which concluded that managers addressing the environmental concern of the customer and mitigate the environmental impact of their products and services have positive financial performance. The result contradicts the study of Scheneitz and Epstien (2005) on exploring the financial value of reputation for corporate social responsibility which concluded that stock market after environmental crisis have negative impact on organisation's performance.

\subsection{Financial Performance}

Firm financial performance relates to the various subjective measures of how well a firm can use its given assets from primary mode of operation to generate profit. For instance return on sales reveals how much a company earns in relation to its sales, return on assets explain a firm's ability to make use of its assets and return on equity reveals what return investors take for their investments.

The study sought to evaluate financial performance of manufacturing companies listed at Nairobi Securities Exchange market in Kenya in relation to organisation's profit, market share and return on assets. The respondents were asked to indicate in percentage how profit, market share and return on assets given range between Ksh 2,000,000 to $6,000,000$ affected financial performance of manufacturing firms during the period between 2011 to 2015 .

The results were that the financial performance based on profit of the firm that ranged 2,000,000 and below 
in 2011 was $50 \% 2012$ was $45 \% 2013$ was $30 \% 2014$ was $25 \%$ and 2015 was $10 \%$. The financial performance that ranged between 2,000,001$4,000,000,2010$ was $55 \%, 2012$ was $40 \%, 201340 \%$ $201425 \%$ and $201530 \%$. In 2011,2012,2013,2014 and 2015 respectfully the financial performance between 4,000,001 and 6,000,000 was as follows $45 \%$, $50 \%, 30 \%, 37 \%$, and $62 \%$. In 2011,2012,2013,2014 and 2015 respectfully the financial performance that ranged $6,000,001$ and above was $20 \%, 12 \%, 50 \%$, $54 \%$ and $60 \%$

The results were that the financial performance based on market share of the firm that ranged 2,000,000 and below in 2011 was 45\% 2012 was $40 \% 2013$ was $35 \% 2014$ was $20 \%$ and 2015 was $40 \%$. The financial performance that ranged between $2,000,001$ $4,000,000,2010$ was $25 \%, 2012$ was $25 \%, 201335 \%$ $201430 \%$ and 2015 10\%. In 2011,2012,2013,2014 and 2015 respectfully the financial performance between $4,000,001$ and $6,000,000$ was as follows $25 \%$, $40 \%, 40 \%, 34 \%$, and 48\%. In 2011,2012,2013,2014 and 2015 respectfully the financial performance that ranged $6,000,001$ and above was $24 \%, 32 \%, 43 \%$, $58 \%$ and $47 \%$

The results were that the financial performance based on ROA of the firm that ranged 2,000,000 and below in 2011 was $42 \% 2012$ was $39 \% 2013$ was $28 \% 2014$ was $22 \%$ and 2015 was $15 \%$. The financial performance that ranged between 2,000,001$4,000,000,2010$ was $51 \%, 2012$ was $38 \%, 201334 \%$ $201423 \%$ and $201525 \%$. In 2011,2012,2013,2014 and 2015 respectfully the financial performance between $4,000,001$ and $6,000,000$ was as follows $40 \%$, $47 \%, 25 \%, 31 \%$, and $40 \%$. In 2011,2012,2013,2014 and 2015 respectfully the financial performance that ranged $6,000,001$ and above was $25 \%, 30 \%, 46 \%$, $50 \%$ and $55 \%$

\section{Summary, Conclusions and Recommendations 5.1 Introduction}

This is the final chapter in this study which gives the summary of the findings, the discussion, conclusions, recommendations of the study based on the objective of the study and suggestions for further findings. It comes after identifying the background, problem at hand and the objectives in chapter one, literature review was done in chapter two, chapter three set out the methodology that the study used to collect data and chapter four analyzed the data obtained from the study.

\subsection{Summary of the Study}

The general objective of this study was to establish the effects of human resource, marketing and environmental management on financial performance of manufacturing firms listed at Nairobi Securities Exchange market in Kenya.

The first objective of the study was to determine the effect of human resource management on financial performance of manufacturing firms listed at Nairobi Securities Exchange in Kenya. The study sought to determine the effect of human resource management on financial performance with respect of the following measures; selection and recruitment, training and development and succession and career path. The study found a positive and significant relationship between selection and recruitment and financial performance of manufacturing firms listed in the NSE in Kenya with a P-Value of 0.000 . The study also found a positive and significant relationship between training and development and financial performance of manufacturing firms listed at NSE with a P-Value of 0.000 . The study again found a positive and significant relationship between succession and career path and financial performance of manufacturing firms listed at NSE with a P-Value of 0.000 .

The second objective of the study was to determine the effect of marketing management on financial performance of manufacturing firms listed at Nairobi Securities Exchange market in Kenya. The study sought to determine the effect of marketing management on financial performance with respect of the following measures; Marketing Planning, Market Analysis and Evaluation and Marketing Control. The study found out a positive and significant relationship between market planning and financial performance of manufacturing firms listed at NSE with a P-Value of 0.000 . The study also found a positive and significant relationship between market analysis and evaluation and financial performance of manufacturing firms listed at NSE with a P-Value of 0.000 . The study again found a positive and significant relationship between marketing control and financial performance of manufacturing firms listed at NSE with a P-Value of 0.000 .

The third objective of the study was to determine the effect of environment management on financial performance of manufacturing firms listed at Nairobi Securities Exchange market in Kenya. The study 
sought to determine the effect of environmental management on financial performance with respect of the following measures; laws and regulations compliance, recycling of wastes and environmental planning. The study found a positive and significant relationship between laws and regulations compliance and financial performance of manufacturing firms listed at NSE with a P-Value of 0.015 . The study also found a positive and significant relationship between recycling of wastes and financial performance of manufacturing firms listed at NSE with a P-Value of 0.000 . The study again found a positive and significant relationship between environmental planning and financial performance of manufacturing firms listed at NSE with a P-Value of 0.075

\subsection{Conclusion of the Study}

Firstly, the study concluded that there was a positive and significant relationship between human resource management and financial performance of manufacturing firms listed at NSE in Kenya. This was drawn from individual components study which concluded that there was a significant positive relationship between selection and recruitment on financial performance of manufacturing firms listed at Nairobi Securities Exchange in Kenya. There was positive and significant relationship between succession and career path on financial performance of manufacturing firms listed at Nairobi Securities Exchange in Kenya. Training and development also indicated a positive and significant influence on financial performance of manufacturing firms listed at Nairobi Securities Exchange in Kenya.

Secondly, the study concluded that there was a positive and significant relationship between marketing management on financial performance of manufacturing firms listed at Nairobi Securities Exchange in Kenya. The study established that majority of the respondent agreed that marketing planning affects financial performance of manufacturing firms. Marketing planning was positive and significant on financial performance of manufacturing firms listed at Nairobi Securities Exchange in Kenya. The study also concluded that majority of the respondent agreed market analysis affected positively and significantly financial performance. Market analysis and evaluation positively influenced financial performance of manufacturing firms listed at Nairobi Securities Exchange in Kenya.
The study thirdly concluded that environment management influenced financial performance of manufacturing firms listed at Nairobi Securities Exchange in Kenya. The study established that majority of the respondent agreed that laws and regulations compliance affected financial performance of manufacturing firms listed at NSE. Recycling of wastes was found to positively and significantly affect financial performance of manufacturing firms listed at Nairobi Securities Exchange in Kenya. The study established that majority of the respondent agreed environmental planning affected financial performance of manufacturing firms listed at NSE. Environmental planning positively influenced financial performance of manufacturing firms listed at Nairobi Securities Exchange in Kenya.

The study also concluded that profit of the firm as a measure of financial performance rated higher than market share and ROA hence should be considered in evaluating firms' financial performance

\subsection{Recommendation of the Study}

From the conclusions of the study, a number of new knowledge have emerged which can assist financial performance of manufacturing firms listed at Nairobi Securities Exchange in Kenya. The first variable argued that human resource management is a significant component in a business operation and specifically the manufacturing firms listed at the NSE should improve on succession and career path of workers in the organization to motivate and improve staff performance in the organization since it rated to a high percentage. Efficient Human resource management influences financial performance of manufacturing firms listed at NSE.

Secondly the findings explained that marketing management as a tool from economics and competitive strategy to analyze the industry context in which manufacturing firm operates has great influence on financial performance. Manufacturing firms should ensure that they base their operations on marketing control tools in order to improve financial performance since it is highly rated among marketing management tools affecting financial performance of manufacturing firms listed at NSE.

Finally the study urged that environmental management should be practiced keenly by stakeholders of the manufacturing firms. Most environment management tool to be employed should 
be recycling of wastes of manufacturing firms so that physical environment is made habitable and at the same time profitability of the firms. Improved decision making to carry out land development with the consideration given to the natural environment should be made to create sustainable community and firm's relationship.

\subsubsection{Suggestions for Further Research}

The current research was based on a descriptive research design on the manufacturing firms within a period of five years. Future studies should be undertaken through a case study for a longer time period which will help in finding in-depth investigation of a single group or event. Depending on available data, future studies on financial performance may include additional explanatory variables as well as enlargement of used population in a way that it involves cross-country analysis.

Further research should be conducted on the same topic with different companies and extending the years of the population. The research should be undertaken which analyses the different sectors in the economy to determine any significant differences in the relationship between firm characteristics and financial performance in the different sectors incorporating more independent variables and also taking into account the prevailing macroeconomic situations.

The study also recommends that further research be conducted in other countries to be able to find out the outcomes in different environments since different countries have different micro and macro environmental influences. The similar study be done in other sectors like private sector, NGOs and SMEs so that a comparison is made as far as financial performance is concerned.

\section{REFERENCES}

1. Adegboyega, I., Dele, A. and Ayodeji, B (2015) Effect of absenteeism on corporate performance: a case study of Cadbury Nigeria. British Journal of Marketing Studies Vol.3, No.2,pp.58- 71, March 2015

2. Ahmed, N. S. (2013). The Non- Financial Factors Influencing the Performance of Islamic Insurance in Kenya: A Case Study of Takaful Insurance of Africa. European Journal of Business and Management Vol.5, No.13, 2013
3. Ahmad, S. and R. G. Schroeder (2003). 'The impact of human resource management practices on operational performance: recognizing country and industry differences', Journal of Operations Management, Vol. 3, No.21, 2003 pp. 19-43.

4. Alam, T. \& Shahi, M. (2012). Factors Affecting Job Satisfaction, Motivation and Turnover Rate of Medical Promotion Officer (MPO) in Pharmaceutical Industry: A Study Based in Khulna City. Asian Business Review, Vol. 1, 2012(1), 126131.

5. Almajali, Y. A., Alamro, S. H., \& Al-Soub, Y. Z. (2012). Factors Affecting the Financial Performance of Jordanian Insurance Companies Listed at Amman Stock Exchange. Journal of Management Research, Vol. 2, No. 4, 2012 (2)

6. American Association for Public Opinion Research (AAPOR). "Response Rates - An Overview." $29 \quad$ Sept 2008. http://www.aapor.org/Education-Resources/ForResearchers/Poll-Survey-FAQ/Response-RatesAn-Overview.aspx

7. Anderson, C. (2013), "Mexico: the new China", available at:opinion/sunday/the-tijuanaconnectiona-template-for-growth.html?_r1/40 (accessed April 22, 2015).

8. Arthur, J. B. (1994). 'Effects of human resource systems on manufacturing performance and turnover', International Academy of Management Journal, Vol. 3, No.37, 1994, pp.670-687.

9. Awino, Z. B., (2011) Strategic Management: An Empirical Investigation of Selected Strategy Variables on Firms Performance: A Study Of Supply Chain Management In Large Private Manufacturing Firms In Kenya. Business Administration and Management, Prime journal Vol. 1No.(1),2011 pp. 09-18

10. Baines, P., Fill, C. and Page, K.(2008) 'Marketing', Oxford University Press.

11. Barnett, M. L. (2007). Stakeholder influence capacity and the variability of financial returns to corporate social response. Academy of Management Review, Vol. 3, No.32 (3), 2008, pg 794-816.

12. Batt, R. (2002). 'Managing customer services: Human resource practices, quit rates, and sales growth', International Academy of Management Journal, Vol. 3, No.45, 2002, pp.587-597. 
13. Beck, T, Cull R, Fuchs M, Getenga J, Gatere P, Randa J, and Trandafir M., (2010), Banking Sector Stability, Efficiency, and Outreach in Kenya. The World Bank Policy Research Working Paper Vol. 6, No.54.

14. Boudreau, J. W. (2003). Sustainability and the Talentship Paradigm: Strategic Human Resource Management beyond the Bottom Line. CAHRS Working Paper Series.

15. Budd, J. W. 2004. Employment with a human face: balancing efficiency, equity, and voice. Ithaca: ILR Press an imprint of Cornell University Press.

16. Carbone, V., \& Moatti, V. (2008). Greening the supply chain: Preliminary results of a global survey. Supply Chain Forum: An International Journal, Vol. 4, No.9, 2008, 66-76.

17. Carreta, A., Farina, V., (2010), Assessing effectiveness and compliance of banking boards, Journal of financial Regulation and compliance, 18, (4) 356-369.

18. Cascio, W. \& Boudreau, J. W. (2010). Investing in People: Financial Impact of Human Resource Initiatives. Upper Saddle River, NJ: FT Press.

19. Clarkson, M. B. E. (1995). A stakeholder framework for analyzing and evaluating corporate social performance. Academy of Management Review, Vol. 3, No.20 (1), 92-117.

20. Clarkson, P. M., Li, Y., Richardson, G. D., \& Vasvari, F. P. (2008). Revisiting the relation between environmental performance and environmental disclosure: An empirical analysis. Accounting, Organizations and Society, Vol. 1, No.33, 303-327.

21. Contractor, N. 2009. "The emergence of multidimensional networks." Journal of Computer Mediated Communication Vol. 2, No 14:743-747.

22. Coombs, J. E., \& Gilley, K. M. (2005). Stakeholder management as predictor of CEO compensation: main effects and interaction with financial performance. Strategic Management Journal, Vol. 2, No.26 (9), 827-840.

23. Cooper, D. R. and Schindler, P. S. (2007) Business Research Methods, McGraw-Hill

24. Cooper, D., \& Schlinder, P. (2011). Business Research Methods, 11 ${ }^{\text {th }}$ Edition, McGraw-Hill Higher Education
25. Creswell, J. W. (2012). Qualitative inquiry \& research design: Choosing among five approaches (4th ed.). Thousand Oaks, CA: Sage.

26. Dibb, S., Simkin, L., Pride, W. M. and Ferrell,O.C.(2006) 'Marketing: Concepts and Strategies', Edition 5. Houghton Mifflin International Inc.

27. Ditlev- Simonsen, C and Midttun, A (2011). What motivates managers to pursue Corporate Social Responsibility (CSR)? Corporate Social Responsibility and Environmental Management, Corp. Soc. Responsib. Environ. Mgmt. Vol. 6, No.18, 25-38 (2011)

28. Dowel, G., Hart, S., Yeung, B. (2000). Do corporate global environmental standards create or destroy market value? Management Science, Vol. 4, No.46, 1059-1074.

29. Evan, W. M., Freeman, R. E. (1993). A stakeholder theory of the modern corporation: Katian capitalism. In Donaldson, T., \& Werhane, P. H. (Eds.) Ethical issues in business. Vol. 3, No. 21(pp. 166-71). Englewood Cliffs, NJ: PrenticeHall.

30. Filbeck, G., Gorman, R. F. (2004). The Relationship between the Environmental Performance and Financial Performance of Public Utilities. Environmental and Resource Economics, Kluwer Academic Publishers, Netherlands.

31. Fiori, G., Donato, F., \& Izzo, F., (2009). Corporate social responsibility and firm's performance. An analysis on Italian listed companies. Presented at the Performance Measurement Association Conference, Vol. 6, No.21 (pp. 266-271).

32. Freeman, R. E. (1984). Strategic management: a stakeholder approach. Boston: Pitman.

33. Gaudine A. P and Saks A. M. (2001). Effects of absenteeism on feedback intervention on employee absence behaviour. Journal of organisational behaviour. Vol2 No.22 (1). 2001

34. Ghosh, M., Dutta, S., Stremersch, S. (2006). Customizing complex products: When should the vendor take control? Journal of Marketing Research, Vol. 3, No.43 (4), 664-679.

35. Githinji, S. (2014). The effect of staff turnover on financial performance of private security firms in Kenya. Human Resources Research paper Vol 1, 2014 
36. Gouldson, A. 2004. Cooperation and the capacity for control: Regulatory styles and the evolving influence of environmental regulations in the UK. Environment and Planning C: Government and Policy, Vol. 2, No.22: 583-603.

37. Goukasian, L., \& Whitney, L., (2008). Corporate Socially Responsible Firms Perform Well! Evidence from Financial and Operating Performances. Working Paper Series Vol. 8, No.12:321-346

38. Guest, D. E. (2011). Human Resource Management and Performance: Still Searching for Some Answers. Human Resource Management Journal, Vol. 3, No. 21(1), 3-13.

39. Gundlach, G. T., \& Wilkie, W. L. (2010). Stakeholder marketing: Why "stakeholder" was omitted from the American marketing association's official 2007 definition of marketing and why the future is bright for stakeholder marketing. Journal of Public Policy \& Marketing, 29(1), 89-92.

40. Hallgren, M., Olhager, J. and Schroeder, R.G. (2011), "A hybrid model of competitive capabilities", International Journal of Operations \& Production Management, Vol. 31 No. 5, pp. 511-526.

41. Heide, J. B. (2003). Plural governance/in industrial purchasing. Journal of Marketing, Vol. 6, No.67 (4), 18-29.

42. Hull, E., \& Rothenberg, S., (2008).Firm performance, the interactions of corporate social performance with innovation and industry differentiation. Strategic Management Journal Vol. 3, No. 63(3), pp 32-41.

43. Jackson, K., 2008. " De-biasing Scale Compatibility Effects When Investors Use Nonfinancial Measures to Screen Potential Investments" contemporary Accounting Research Journal, Vol. 2, No 25: 803-826.

44. Jensen, M. (2001). Value maximization, stakeholder theory, and the corporate objective function. Journal of Applied Corporate Finance, Vol. 5, No.14 (3), 8-21.

45. Jensen, M. (2003). A theory of the firm. Governance, Residual Claims, and Organizational Forms. International Journal of Project Management, Vol. 3, No.19 (4), 195-205.
46. Kanning, U. P. \& N. Bergmann, N. (2009). Predictors of Customer Satisfaction: Testing the classical paradigms. Managing Service Quality. An International Journal, Vol.19, No. 4, pp. 377390.

47. Kargar, J., \& Parnell, J. A. (2009). Strategic Planning Emphasis and Planning Satisfaction in Small Firms; An Empirical Investigation. Journal of Business Strategies, Vol. 7, No.13 (1), 42-64.

48. KAM (2011, February 7). Kenya's Economic Outlook, 2011. Retrieved from http://www.kam.co.ke/?itemld=17\&newsld=459.

49. Kierman, M. (1998). The eco-efficiency revolution on organization performance. Investment horizon, April, 68-70.

50. Kimosop, D. J. (2007). Labour Turnover in Private Security Firms in Kenya: A Case Study of Future Force Security Firm. Nairobi, KE: University of Nairobi.

51. KNBS (2012), Leading Economic Indicators. Kenya National Bureau of Statistics.

52. KNBS (2016), Leading Economic Indicators. Kenya National Bureau of Statistics

53. Kombo, F. (2015) Customer satisfaction in the Kenyan banking industry Journal of International Studies, Vol. 8, No 2, 2015, pp. 174-186.

54. KPMG (2014). Kenya-Business Environment Survey. Available at kpmg.com/Africa

55. Lee, J., and Roh, J. J. (2012). Revisiting corporate reputation and firm performance link. An International Journal, 19 (4), 649-664.

56. Li, D. X., (2000). On Default Correlation between Marketing and Financial Performance: A Copula Function Approach Vol. 2, No. 2(3), 1998

57. Liao, Y. S. (2005). 'Business strategy and performance: the role of human resource management control', Personnel Review, Vol. 3, No.34(3), pp.294.

58. Logan, M. S. (2000). Using Agency Theory to design successful outsourcing relation-ships. International Journal of Logistics Management, Vol.2, No 11(2), 21-32.

59. Mariappanadar, S. (2012a). Harm of Efficiency Oriented HRM Practices on Stakeholders: an Ethical Issue for Sustainability. Society and Business Review, Vol. 7 Iss: 2 pp. 168 
60. Maru, L., Chepkwony, J. and Menjo, K. (2012) Recycling of waste as a determinant of financial performance of Small and medium enterprises in Eldoret Town, Kenya. Prime Research on Education (PRE) Vol. 3(4), pp. 479- 483, May $31^{\text {st }}$, 2013 www.primejournal.org/PRE

61. Millar, M. M., \& Dillman, D. A. (2011). Improving response to web and mixed-mode surveys.Public Opinion Quarterly, nfr003.

62. Mochache, P. N. (2015). Effect of Non-Financial Factors on Business Performance of Women Entrepreneurs in Service Industry in Kenya: A Case of Kisii County. Journal of Entrepreneurship and Business Innovation, 2015 Vol 2 No. 1

63. Moore, S. D. \& McCabe, G. P. (2003). Introduction to the Practice of Statistics. W. H. Freeman and Company, New York.

64. Mutua, E. (2014) Report on the policy, legal and regulatory framework in the extractive industry of Kenya. Consideration of the interests of local communities, women, youth and the vulnerable, and the environmental sustainability of the industry. A comparative study of Turkana, Kitui and Kwale counties of Kenya

65. Mugenda, M., \& Mugenda, G., (2012). Research methods dictionary. Nairobi Acts Press.

66. Murphy, E. (2012). Key Success Factors for Achieving Green Supply Chain Performance; $A$ study of UK ISO 14001 Certified Manufacturers. (PhD thesis, The University of Hull) Vol. 2, No. 23(1)

67. Murray, A., Sinclair, D., Power, D., Gray, R. (2006). Do market financial market care about social and environmental disclosure?.Auditing and accountability journal, Vol. 3, No.19, 228-255.

68. Naila, D. L. (2013). The Effect of Environmental Regulations on Financial Performance in Tanzania: A Survey of Manufacturing Companies Quoted on the Dar Es Salaam Stock Exchange. International Journal of Economics and Financial Issues Vol. 3, No. 1, 2013, pp.99-112

69. Nairobi Securities Exchange, (2013, July 24). NSE Hand book 2012. Retrieved on July 24, 2013, from www.nse.org

70. Olavarrieta S and Friedmann R (2007). Market orientation, Knowledge related resources and firm performance. Journal of Business Research Vol. 4, No.16 (3) J3- 380.

71. Owino E. O. (2013). The Influence control of service quality and corporate image on customer satisfaction among university students in Kenya, Unpublished PhD Thesis). School of Business, University of Nairobi.

72. Patton, M. Q. (2002). Qualitative research \& evaluation methods (3rd ed.). Thousand Oaks, CA: Sage.

73. Preuss, G. A. (2003). High performance work systems and organizational outcomes: The mediating role of information quality. Industrial and Labor Relations Review Journal Vol. 3 No.6(2)

74. Qi, Y. (2010). The Impact of the Budgeting Process on Performance in Small and MediumSized Firms in China (Doctoral Dissertation, University of Twenty, China).

75. Raju, P. S. and S. C. Lonial (2002). 'The impact of service quality and marketing on financial performance in the hospital industry: an empirical examination', Journal of Retailing and Consumer Services, Vol. 3, No.9, pp.335-348.

76. Republic of Kenya, (2014). Kenya.um.dk.Economy.Availableat:http://kenya.u m.dk/en/about-kenya-new/economy-new//

77. Robert, P. W., \& Dowling, G. R. (2002). Corporate reputation and sustained superior Performance. Strategic Management Journal, 23 (2), 1077-1093.

78. Rowley, T. 1997. Moving beyond dyadic ties: A network theory of stakeholder influences. Academy of Management Journal, Vol. 3, No.22: 887-910.

79. Salehi, M. A., Ghazal, S., Moein D. M. (2013), the relationship between social responsibility and financial performance of listed companies on the Stock Exchange, Vol III, Issue 9,

80. Sen, S., Bhattacharya, C. B., \& Korschun, D. (2006). The role of corporate social responsibility in strengthening multiple stake-holder relationships: A field experiment. Journal of the Academy of Marketing Science, 34(2), 158-166.

81. Saunders, M., Lewis, P. \& Thornhill, A. (2009). Research Methods for Business Students, (5th Ed.). Harlow: FT/Prentice Hall. 
82. Schmenner, R.W. and Tatikonda, M. V. (2005), "Manufacturing process flexibility revisited", International Journal of Operations \& Production Management, Vol. 25 No. 12, pp. 11831189.

83. Schnietz, K., Epstien, M. (2005). Exploring the financial value of reputation for corporate social responsibility. Corporate Reputation Review, Vol. 3, No. 7, 327-345.

84. Shaw, W. 2012. 'Will Emerging Economies Repeat the Mistakes of Their Rich Cousins?' International Economic Bulletin March.

85. Sozen, H. C. (2012). Social networks and power in organizations: A research on the roles and positions of the junior level secretaries in an organizational network, Personnel Review, Vol. 41 Issue: 4, pp.487-512

86. Stanwick, S., \& Stanwick, P. (2000). The relationship between environmental disclosures and financial performance: An empirical study of US corporations. Eco-Management and Auditing, Vol. 6, No.7, 155-164.

87. Stenbacka, C. (2001). Qualitative Research Requires Quality Concepts of its Own, Management Decision, 39(7), 551-555.

88. Thirwall, A. P. (2005). Growth and Development: With Special Reference to Developing Economies ( ${ }^{\text {th }}$ Edition). Palgrave Macmillan.

89. Thompson, V. A. (2007). Bureaucracy and innovation. Administrative Science Quarterly, 10, $1-$

90. Thom, N. \& Zaugg, R. J. (2004). Nachhaltiges and Innovative Personal management: Spitzengruppenbefragung in europäischen Unternehmungen und Institutionen, Wiesbaden: Gabler. http://dx.doi.org/10.1007/978-3-663 10862-7_11

91. Trochim, W. M. K. (2006). Research Methods Knowledge Base. Natorp Boulevard Mason: Atomic Dog. Retrieved from http://www.socialresearchmethods.net/kb/reltypes. php

92. UN (2007). The millennium Developed Goals report. http://ww.un.org/millenium goal (Accessed September 18, 2007).

93. Upton, HF 2011, The Deepwater Horizon oil spill and the Gulf of Mexico fishing industry. Retrieved from http://www.fas.org/sgp/crs/misc/R41640.pdf
94. Vance, D. (2009). Corporate Restructuring: From Cause Analysis to Execution. New York, NY: Springer Science \& Business Media.

95. Wagana, D. \& Kabare, K. (2015). The influence of Corporate Governance on Corporate Performance among Manufacturing Firms in Kenya: A Theoretical Model. International Journal of Academic Research in Business and Social Sciences, Vol. 5,

96. Walker, D. (2001). Exploring the Human Capital Contribution to Productivity, Profitability and the Market Evaluation of the Firm. Retrieved from lib.umi.com: http:/wwwlib.umi.com/dissertations.

97. Wanyama, K. and Mutsoso, S. (2010). Relationship between capacity building and employee productivity on performance of commercial banks in Kenya. African Journal of History and Culture Vol. 2(5), pp. 73-78, 2010

98. Weed, T. (2004). The importance of customer profitability. Automotive Industries, Vol. 3, No.184 (8), 40-41.

99. Weidinger, C. and Platts, K. (2012). Evaluating the Effectiveness of Performance Measurement Systems. Seventeenth International Working Seminar on Production Economics. Austria: Innsbruck.

100. Winter, G. (2001). A Comparative Discussion of the Notion of Validity in Qualitative and Quantitative Research, the Qualitative Report, 665-770.

101. WMP (2014). The manufacturing industry in the developing economies, Journal of Business Management, Vol. 4, No. 2, 1, 3-5

102. Wright, P., Mukherji, A. \&Kroll, M. J. (2001). An examination of Agency Theory assumptions: Extensions and extrapolations. The Journal of Socio-economics, Vol. 2, No. 30(5),

103. Yang, Z. (2006). Data Envelopment Analysis Evaluation of Canadian Resource Companies. Paper presented at the Portland International conference on Management of Engineering and Technology 2006 (PICMET) Technology management for the Global future. Journal of Business Management, Vol. 2, No. 2(2006).

104. Zhu, Q., Sarkis, J., \& Lai, K. H. (2006). Green supply chain management: pressures, practices and performance within the Chinese automobile industry. 


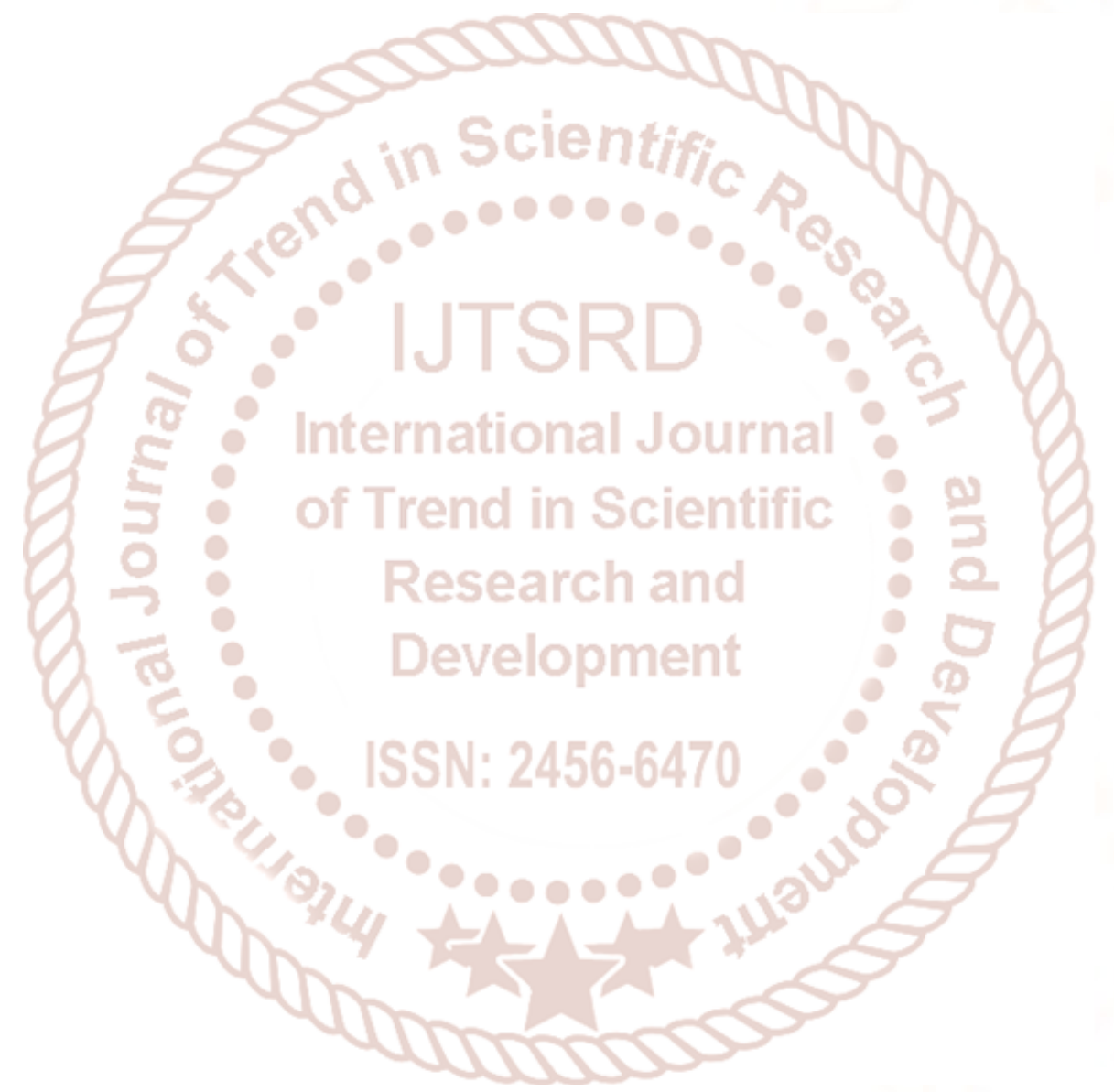

